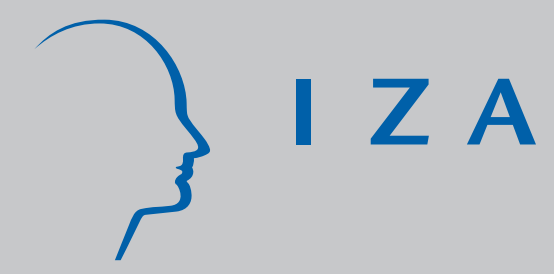

IZA DP No. 125

The Income Portfolio of Immigrants in Germany

- Effects of Ethnic Origin and Assimilation Or: Who Gains from Income Re-Distribution?

Felix Büchel

J oachim R. Frick

March 2000 


\title{
The Income Portfolio of Immigrants in Germany - Effects of Ethnic Origin and Assimilation Or: Who Gains from Income Re-Distribution?
}

\author{
Felix Büchel \\ Max Planck Institute for Human Development MPIB, Berlin \\ and Technical University of Berlin \\ Joachim R. Frick \\ German Institute for Economic Research DIW, Berlin
}

Discussion Paper No. 125
March 2000

IZA

P.O. Box 7240

D-53072 Bonn

Germany

Tel.: +49-228-3894-0

Fax: +49-228-3894-210

Email: iza@iza.org

This Discussion Paper is issued within the framework of IZA's research areas Mobility and Flexibility of Labor Markets and The Welfare State and Labor Markets. Any opinions expressed here are those of the author(s) and not those of the institute. Research disseminated by IZA may include views on policy, but the institute itself takes no institutional policy positions.

The Institute for the Study of Labor (IZA) in Bonn is a local and virtual international research center and a place of communication between science, politics and business. IZA is an independent, nonprofit limited liability company (Gesellschaft mit beschränkter Haftung) supported by the Deutsche Post AG. The center is associated with the University of Bonn and offers a stimulating research environment through its research networks, research support, and visitors and doctoral programs. IZA engages in (i) original and internationally competitive research in all fields of labor economics, (ii) development of policy concepts, and (iii) dissemination of research results and concepts to the interested public. The current research program deals with (1) mobility and flexibility of labor markets, (2) internationalization of labor markets and European integration, (3) the welfare state and labor markets, (4) labor markets in transition, (5) the future of work, (6) project evaluation and (7) general labor economics.

IZA Discussion Papers often represent preliminary work and are circulated to encourage discussion. Citation of such a paper should account for its provisional character. 


\section{ABSTRACT}

\section{The Income Portfolio of Immigrants in Germany - Effects of Ethnic Origin and Assimilation Or: Who Gains from Income Re-Distribution?*}

This paper deals with the economic performance of various population groups in Germany giving special attention to ethnic origin of immigrants as compared to the native born German population. In addition, winners and losers of the re-distribution process, induced by the tax and social security system, are identified. This is done by considering different components of market and non-market income as well as taxes and social security contributions.

This income portfolio analysis is based on data from the German Socio-Economic Panel covering the observation years 1995 to 1997. Population subgroups are made up of West Germans, East Germans, and immigrants; the latter being split into Ethnic Migrants (Aussiedler) and foreigners. Immigrants are differentiated according to their state of assimilation: those immigrants living together with a native born adult German („mixed,, immigrants) and others (.,pure,, immigrants). In order to control for any retirement related impact we run all analyses for the total population as well as for those who live in households with a head of prime age.

Our results show that immigrants are a very heterogeneous group with respect to their economic performance. The well-assimilated "mixed, immigrants have an even better relative income position than the autochthonous West German population.

In general, we confirm the well-known poor market performance of immigrants. However, also immigrants' non-market incomes are atypically low (except for those of „pure,, Aussiedler), mainly due to their age structure, resulting in lower eligibility for and receipt of old age pensions. Non-market incomes of younger immigrants are somewhat higher than those of the autochthonous West German population, but still much lower when compared to the East German population.

\footnotetext{
" This paper was presented at the IZA Workshop "Ethnic Migrants in Labor Market and Society: Integration Experience in Comparison", Bonn, January 29-31, 2000.
} 
Analyzing the re-distribution effect caused by public transfers, old age pensions, and tax and social security contributions, we find that immigrants as a whole are (slightly) net payers. Again, „pure, Aussiedler are an exception. When focusing only on younger people, the situation is reversed, and immigrants profit slightly. This is due to above average non-market income of „pure,, immigrants. However, East Germans are still much better off.

The question which remains to be answered is whether these differences stem from an immigrant specific effect per se or whether they are influenced by underlying social structure differences. Using random-effects models to control for various socio-economic measures, we find that non-German immigrants remain net payers. In addition, immigrants' need of being subsidized by the re-distribution process rapidly and strongly decreases with progressing duration of stay in Germany. On the other hand, the subgroups substantially profiting from the re-distribution process are „pure,, Aussiedler and East Germans. This means --at least in our static "snapshot,, analysis-- that the "classic,, immigrants (of nonGerman nationality) are no economic burden to the autochthonous population.

JEL Classification: J61, J15, J18, D31

Keywords: Immigration, migration policy, income, income re-distribution

\author{
Felix Büchel \\ Max Planck Institute for Human Development \\ Lentzeallee 94 \\ 14195 Berlin \\ Germany \\ Tel.: +49-30-82406-427 \\ Fax: +49-30-82499-39 \\ Email: buechel@mpib-berlin.mpg.de
}




\section{Introduction}

The long-term stability of the --up to now-- well-functioning German corporatist social security system, which in large part is based on a pay-as-you-go mode, is severely endangered by low fertility rates and increasing life expectancy in the autochthonous population. While demographers (cf. United Nations Population Division $2000^{1}$ ) discuss enforced immigration as a possible solution to this lurking most substantial societal problem, the public opinion, including influential politicians, still associate immigration with a burden rather than a relief. It is feared that a below average skill level of immigrants impedes their labor market integration and therefore leads to above average take-up rates of public transfers. In addition, the general ability and willingness for appropriate assimilation is doubted in general. As a consequence, current public discussions tend to focus on how to avoid immigration and not how to support it (Rotte 1998). The former Kohl administration reported: „(As before), today's Germany has no need for further immigration of foreigners,, ${ }^{2}$.

Although immigration rates to Germany over the last decade were the highest among European countries (when neglecting Luxembourg and Switzerland) ${ }^{3}$, the official governments policy was always to consider Germany not as an immigration country. The former Kohl administration explicitly denied the existence of an active immigration policy and, as a consequence, the need for a steering immigration law $^{4}$. Since the elections in October 1998 which led to the change in federal administration, the German Social Democrats realized some steps towards easing the naturalization and allowing temporary dual citizenship for children. Until then, the typical German concept of ethnicity and citizenship was in place, based on „,cultural, linguistic and ethnic,, considerations (see Hailbronner 1992). According to this concept a person born in Germany did not automatically receive German citizenship as would be the case in most other countries (ius soli), but rather that of the parents. On the other hand this concept allows people of German ethnic origin (Aussiedler $)^{5}$ who live outside Germany to claim German citizenship basically when crossing the borderline (ius sanguinis). Nevertheless, plans for a new immigration law are still on hold (Witzsch 1999). The most recent official position is to wait for an immigration law initiative on behalf of the European Union. On the one hand, such a solution would be the most efficient one (Zimmermann 1994b, 1995, Gusy 1994, Gusy and Ziegler 1997, Lohmann 1997). On the other hand, due to generally long decision processes

\footnotetext{
1 The ongoing United Nations project „Replacement Migration: Is it a Solution to Declining and Aging Populations?,, suggests a „Replacement Migration,, of about 500.000 immigrants p.a. for Germany.

Ethnic Germans (,,[Spät-]Aussiedler,,) are German natives and their descendants who lived in Eastern Europe or in the area of former Soviet Union, most of them for generations. According to the German constitution, these people are awarded German citizenship in the case of „re-,,immigration to Germany, if they can proof some basic German language knowledge and German cultural identity (for details see e. g. Zimmermann 1999). The immigration of Ethnic Germans to Germany dropped from about 400.0000 persons in 1990 to about 40.000 persons in the first half of 1999 (see Lederer, Rau, and Rühl 1999).
} 
at the European Union level and discrepancies between the interests of the member states (Zimmermann 1994a), it is evident that this strategy much more favors the status quo than a change ${ }^{6}$. However, the pressure to change the unsatisfactory situation are becoming stronger and considerations about an immigration law are becoming more and more concrete (Wollenschläger 1997, GöbelZimmermann and Masuch 1998). Neglecting the option to actively steer immigration (e. g. with respect to age structure, educational and occupational background, and ethnic origin; cf. Simon 1994) means to abstain from the opportunity to raise welfare in a controlled way (Dicke and Glismann 1995, Scholten and Thum 1996).

In most recent years, immigration patterns in Germany have changed substantially (see figure 1). During the 1960s and early 1970s immigration to Germany was heavily influenced by migrant workers from Mediterranean countries (the so-called ,guest-workers,,), which was clearly reduced by the recruitment halt (Aufnahme-Stopp) in 1973. The inflow of Aussiedler from former Eastern Block countries peaked in the years 1989 and 1990 at about 400,000 persons annually; these figures are meanwhile down to about 100,000 persons per year. On the other hand, the number of asylum seekers and refugees drastically increased until 1992 (mainly due to the Yugoslavian conflict as well as the persecution of Turkish Kurds). When evaluating this process one should also keep in mind changes in the institutional settings like the so-called „Dritt-Staaten-Regelung, introduced in $1993{ }^{7}$ After peaking in 1992 at about 1.5 million persons per year, the total number of immigrants declined almost continuously to about 800,000 in 1998 , while the number of persons leaving Germany remained pretty stable in a range of $3 / 4$ million $+/-100.000$ persons per year.

-- Figure 1 about here --

As a consequence, immigration surplus dropped from plus 782,000 persons in 1992 to almost zero $(47,000)$ in $1998 .^{8}$ On the one hand, this development aggravates the demographic problem with regard to the future of the German social system severely. On the other hand, it may open the door for discussions of the advantages and disadvantages of immigration under less tensioned social conditions than in former times.

However, German society and political players are insufficiently equipped with substantial facts for such a discussion. Even official general population statistics are in rather bad shape or at least do not sufficiently differentiate between migrants and foreigners. Due to data privacy laws recent Aussiedler

\footnotetext{
6 However, this position is very different than that of most German scientists working in this field (GöbelZimmermann and Masuch 1998, Zimmermann 1999). Decidedly opposite opinions such as those of Felderer (1994a) and Birg (1995) are expressions of a minority.

According to this rule persons coming to Germany through a so-called „,safe country,, were no longer allowed to apply for asylum. Germany as such is surrounded by „,safe countries,,, which clearly reduces the number of eligible asylum seekers.
} 
might not be explicitly shown in some official statistics; they rather appear as Germans without being mentioned as immigrants. In addition, there are inconsistencies between the main statistics and specialized subsystems ${ }^{9}$; even the central register of foreigners is blamed for an exaggeration of the real number due to a lack in coverage of re-migration. ${ }^{10}$

Better access to a range of important aspects in the immigration issue is given by the findings of micro-economic analyses. Main fields of research cover social behavior or assimilation of immigrants, including take-up of social transfers, immigrants' labor market integration, and effects of immigration on local labor markets (see Section II). From an economic point of view, the question whether immigrants --or specific subgroups among them-- are rather enriching or burdening the native-born population is another important issue: ,(The) cost-benefit calculation will surely be a key component of the immigration debate that is likely to dominate domestic public policy in the next decade,, (Borjas 1995b, p. 279).

Most of the work in this specific field focuses on differences concerning the receipt of public benefits between immigrants and the native-born population, but neglects the other side of the cost-benefit calculation: „An overall judgment on the effects of immigrants on future government expenditures should take account the tax contributions of immigrants and natives as well as the expenditures for them. However, no recent study provides data on household incomes of natives and immigrants; hence there is no solid basis for estimating the taxes paid by the two groups.,, (Simon 1996, p. 107). Only a very few studies take this into consideration like Börsch-Supan (1994). It is our goal to give a small contribution to this underexposed field of research. After all, the crucial question is: „Do (immigrants) consume more services from the public sector than they pay for in taxes?,, (Schulz 1998: 245) or more specific: „Who's financing whom? Do immigrants subsidize the native population or vice versa? Is immigration a cost factor or a net benefit for the public transfer system?,, (Weber and Straubhaar 1996, p. 350$){ }^{11}$

In this paper, we use representative micro-data taken from the German Socio-Economic Panel Study (GSOEP) in the period 1995 to 1997 (Wagner, Burkhauser, and Behringer 1993; Projektgruppe SOEP 1995). This dataset has sufficiently differentiated information on ethnic origin of immigrants as well as on income. We distinguish between native-born West Germans, East Germans, foreigners and Ethnic German immigrants (Aussiedler). For the latter two groups, we differentiate between households of „pure,, ethnicity and those of „,mixed,, ethnicity, where adults with German nationality are living in a

\footnotetext{
$8 \quad$ For more detailed information cf. Sommer and Voit 1999.

9 Comparing the total of immigrants from the aggregated statistics (1998: 802.000) with that of the specialized subsystem which differentiates between ethnic groups (1998: 631.000), there remains a substantial unexplained difference (Lederer et al. 1999, p. 45.)

10 In 1987, the year of the last official census, there was a difference of 600,000 foreigners between the central register and the census results (see Lederer, Rau, and Rühl 1999).
} 
household with a non native-born head. This is done to cover the assimilation status in a more specific way than usually done. For some analyses which concentrate on the immigrant population we additionally control for duration of stay in Germany.

For these different ethnic groups we analyze volume and structure of pre-government income (=market income) and non-market income. We consider payments of taxes and other contributions to the German tax and welfare system as well as the receipt of public transfers and benefits in order to shed some light on the individual performance of households within the process of income redistribution. Market income consists of employment income, capital income, and private transfers, whereas non-market income components are old age pensions and other public transfers.

Since we are interested in differences in the income performance across the ethnic groups, we first compare relative positions for all income components. Secondly, we calculate for each ethnic group separately: a) the population share receiving a specific income component, b) the most important income component, and c) the various income components as a share of total income (,portfolio structure,,). Two indicators are used to describe the re-distribution impact. In a „head count,, approach we simply calculate for each subgroup the respective share of „winners,, and „losers,,; winners being defined as those persons whose post-government income position is above that based on pregovernment income. We also use the absolute difference between post- and pre-government income positions as a metric measure of individual re-distribution performance.

Basically, we run all analyses first for the entire population of persons living in private households in Germany (the „social burden approach,,), and secondly only for persons in households with a head of prime age (the „labor market integration approach,). This differentiation is thought to take into account expected age effects, which are closely related to different positions in the re-distribution process. This is especially necessary, since the age structure of the considered ethnic groups is most likely to be different.

Additionally, we apply multivariate analyses to find out if differences in the behavior of our selected subgroups are given for those persons per se or if these are just the result of a different social structure. We apply random-effects models to the pooled data-set based on three cross-section years. Simultaneously controlling for various SES measures we repeat the descriptive analyses on pregovernment and post-government incomes as well as changes in the relative income position due to the re-distribution process. This provides us with the information on how the different population groups are profiting from the tax and welfare system, and which of them are overall contributing to it, net of all control variables.

11 The same aspect is pointed out by Wellisch and Wildasin (1996, p. 125). 


\section{Background}

The existing literature contains a large variety of research designs that tackle the question whether immigrants are „burdening,, the native-born population or not in a more or less specific form.

A most unspecified form of analysis is just using a dummy variable to control for foreign nationality or immigration when analyzing any social phenomenon (e.g. for the transition from school to work, see Helberger, Rendtel, and Schwarze 1994). In general, immigrants or foreigners on average show a weaker socio-economic position than the native-born population which very often is interpreted as an indication for immigrants as a whole lowering the welfare position of the autochthonous population. But due to the most heterogeneous social structure of immigrants this standard interpretation is definitely too rash.

Most empirical research which explicitly focuses on immigrants can be clustered into some very few sub-topics (for an overview see Schultz 1998).

A variety of analyses deal with the question of social integration of immigrants. Reitz (1998) approaches this topic in a broader way, taking into account institutional settings. Frick, Smeeding, and Wagner (1999) consider the social heterogeneity of the immigrant population by controlling for differences in labor market behavior and income for different ethnic groups and immigration cohorts. A lack of assimilation is considered to complicate the labor market integration process (Zimmermann 1999). Reversing the research angle, Dustmann (1996) found that economic success as a condition for assimilation seems to be of less importance. There are some studies with special focus on ethnic migrants. Koller (1997) states a generally high tendency for assimilation in this group. Dietz (1999) finds that moving into an existing social network eases the way to economic integration for them. The same is stated by Bauer and Zimmermann (1997); however, they also find that social networking within the group of ethnic origin lowers the chances for social assimilation. When analyzing social integration, a long-term perspective is of special interest. In this context, longitudinal data are very helpful (cf. Fielding 1995). Seifert (1997) shows clear differences between first and second generation immigrants' behavior. In general, changes in the social structure of immigrants (e.g. Borjas 1985, 1994, 1995a) have an effect on assimilation opportunities, too. Another approach is to focus on intergenerational status mobility, e.g. with respect to educational behavior (Büchel and Wagner 1996, Haisken-DeNew, Büchel, and Wagner 1997, Gang and Zimmermann 1999). 
Another type of analysis focuses on labor market integration of immigrants. Broad approaches to the topic are rare (Velling 1995, Bauer 1998). In general, the earning patterns of immigrants are compared to those of the native-born population (cf. Schmidt 1993, 1997, Winkelmann and Winkelmann 1998, Reitz et al. 1999). Chiswick and Miller (1994) analyze immigrants' investments in human capital. With respect to ethnic migrants, some specific studies are available (Ulrich 1994b, Dunn, Kreyenfeld, and Lovely 1997, Bauer and Zimmermann 1999).

An important topic is the effect of immigration on the structure of the host country's labor markets. A extended attempt to answer this question was made by Hatton and Williamson (1994). In general, the effects are considered to be low (cf. LaLonde and Topel 1991, Gang and Rivera-Batiz 1994, Velling 1995, Pischke and Velling 1997). DeNew and Zimmermann (1994) found a negative impact of immigration on wages in Germany. This is the result theoretically to be expected (von Zameck 1993). Nevertheless, an opposite result for Austria was presented by Winter-Ebmer and Zweimüller (1996). Börsch-Supan (1994) finds that only gross wages, but not net wages are negatively affected by immigration. Axelsson and Westerlund (1998) find no significant effect on real disposable household income from migration for Sweden over the period of the 1980s. Frick et al. (1997) as well as Grabka, Schwarze, and Wagner (1999) extend the field of analysis by focusing on changes in the income distribution due to immigration. They both find a rather small increase in inequality. A related topic is analyzed by Müller (1995) who comes to the unsurprising result that assimilation among immigrants is easier for those who are able to import higher capital resources than for others.

Another major field of research is that of take-up of public transfers. The receipt of welfare benefits is of special interest (cf. Jensen 1988, Maani 1993, Khoo 1994, Gustman and Steinmeier 1998, Riphahn 1998, Hu 1998). The general expectation is that take-up intensity among immigrants decreases with increasing duration of stay (Büchel, Frick, and Voges 1997, Voges, Frick, and Büchel, 1998). However, a contrary result is presented by Baker and Benjamin (1995) as well as by Borjas and Trejo (1995). This could be explained by varying institutional settings between countries. Borjas and Hilton (1996) believe that social networks among immigrants lead to higher take-up rates of this group. However, this is challenged by Zavodny (1997). Voges, Frick, and Büchel (1998) as well as Bird et al. (1999) state that welfare recipiency is higher among immigrants than among native-born people, and the latter even find that take-up shares among immigrants are above average in the case of eligibility. However, both studies conclude that this is due to the less favorable social structure of immigrants, i.e. that different ethnic origin is not a risk factor per se.

Analyses considering the structure of the whole welfare system are rather rare compared to those following ,traditional,, empirical designs. Sinn (1997) suggests -- with special regard to immigration -at least a partial transition from the existing pay-as-you-go system to a funded system. 
Finally, some studies exist in the field we are especially interested in, i.e. the analysis whether a given society is economically burdened or -- in contrast -- is profiting by immigration. Trying to find an answer to this question requires a design considering both aspects simultaneously, the receipt of benefits and the contribution to the tax and welfare system. LaLonde and Topel (1991) report that immigrants to the USA have lower incomes, but bear this burden for themselves, that is without affecting the native-born population in a severe way. Simon (1996) confirms this finding for the US in the 1970s; however the picture for more recent periods is not that clear. The study of Rürup and Sesselmeier (1994) states that immigrants to Germany are net payers with respect to the unemployment insurance and the medical aid system; with respect to the old age pension system, the results seem too be less obvious because of uncontrollable and unpredictable interdependent effects. For Switzerland, Weber and Straubhaar (1996) find that immigrants are net payers to the tax and social security system ${ }^{12}$. The following empirical work for the case of Germany should be seen in the tradition of this type of immigration research.

\section{Data and Methods}

\section{Data and Observation Period}

All following empirical analyses are based on representative micro-data from the German SocioEconomic Panel (GSOEP), which is an ongoing panel survey with a yearly re-interview design. This data-set provides data at the household and the individual level (Wagner, Burkhauser, and Behringer 1993) as well as specific information about ethnic origin of respondents and household structure. We match the German portion of the PSID-GSOEP-Equivalent File (Burkhauser, Butrica, and Daly 2000) for most detailed information about various components of household income ${ }^{13}$. We analyze data collected in years of interview from 1995 to 1997, which include data from a new sub-sample started in 1994/95 which is especially designed to cover immigration to Germany since 1984 (see figure 1) when the original sample was drawn (Burkhauser, Kreyenfeld, and Wagner 1997). Because we analyze retrospectively asked income information concerning the year preceding the interview, our analysis covers incomes for the years 1994 to 1996. In the descriptive analyses, appropriate weighting factors are applied. Our pooled three-years sample contains 52.050 persons with valid income information, 45.495 of them living in households with a head of prime age, and 12.564 of them living in immigrant households ${ }^{14}$.

\footnotetext{
12 Additional studies are reported in Weber and Straubhaar (1996, Table 1, p. 335).

13 Since the GSOEP collects only information on gross income, a simulation module is being used to calculate individual tax and social security contribution (c.f. Schwarze 1995).

14 Note the oversampling of immigrants in the GSOEP population. We consider this aspect using appropriate weights.
} 
Level of Analysis and Definition of Ethnic Groups

Unit of analysis is the individual in his respective household context. Households are categorized into different ethnic groups according to the ethnicity of the adult ${ }^{15}$ household members. The ethnic origin of the head of household determines the main categorization. Contrary to the more technical definition of the GSOEP administration, we define the household member earning the highest individual income to be the head of household ${ }^{16}$. After categorization at the household level, all members of a household (including dependent children) are given the same status concerning ethnicity, regardless of their legal nationality.

In West Germany, we distinguish between: i) Native-born Germans; ii) „Pure, Ethnic Germans (all adults household members are Ethnic Germans); iii) „Mixed,, Ethnic Germans (head of household is Ethnic German; at least one other adult household member is native-born German); iv) „Pure, foreigners (no adult household member has German nationality); v) „Mixed,, foreigners (head of household has no German nationality; at least one other adult household member is native-born German $)^{17}$. Due to still persisting strong differences in income structures between West and East Germany, we finally differentiate vi) East Germans ${ }^{18}$.

\section{Income Components, Relative Income Positions, and Re-Distribution}

Although we analyze income at the level of persons, income information is calculated at the household level ${ }^{19}$. The underlying assumption of this approach is that all members of a specific household pool their resources and share the same utility from a given household income. Consequently, we match the information about the various (equivalent) income components of a specific household to all members of that household, regardless of age or individual income performance.

In order to adjust for differences in household size, we apply an equivalence scale with an elasticity of $\varepsilon=.5$ which approximates the so-called OECD scale. All income components are deflated and

\footnotetext{
15 The GSOEP defines ,,adults,, as persons aged 17 years and older.

16 In case of different adult household members showing the same individual income, the head of household according to GSOEP definition is the person who knows best about the household's socio-economic conditions.

17 We analyze all German households. Some very few „mixed,, households with Ethnic Germans and foreigners are grouped into the „pure,, Ethnic German category. Note: the foreigners' group contains some few asylum seekers living in private households (the vast majority of asylum seekers lives in institutional arrangements which are not part of the GSOEP sample). See Schmidt and Weick (1998) for some more detailed information on the increasing number of partnerships and marriages between German and foreign citizens.

18 To be more precise: ,households in East Germany,.. This includes some very few foreigners as well. Note that the use of the term ,ethnic group, has no substantial meaning when distinguishing between East and West Germans (who are of same ethnic origin, of course).

19 This is done because the receipt of some income components (like social assistance) is related to the households as a whole and not to specific individuals living in a household.
} 
expressed in 1995 DM. The amounts are adjusted for purchasing power differences between West and East Germany (about 7\% p.a.). We apply a bottom and top trimming by eliminating the lowest and highest .5 percent of per capita post-government incomes to reduce the effect of extreme income outliers. Finally, we pool the observations across all three cross-sectional years; the results yield the average of the period 1994 to 1996.

Given our interest in differences between immigrants and the autochthonous population, we analyze the following income components for each of the subgroups described above: i) employment income; ii) capital income (including imputed rent for owner-occupied housing); iii) private transfers (including old age pensions from former employers or firms ${ }^{20}$ ). Adding these three components, we obtain the pre-government income. Adding iv) old age pensions and v) public transfers to it, and subtracting vi) taxes and social security contributions from the pre-government income results in postgovernment income.

All income components are standardized by relating individual income to the respective mean of the total German population (Total Mean $=100 \%$ ). The effect of re-distribution is measured by two indicators: i) subtracting for each individual the relative income position based on pre-government income from the one based on post-government income yields a metric measure which is positive (negative) for those who improve (worsen) their income position due to re-distribution process; ii) a second indicator is given by a dummy-variable just indicating winners and losers of re-distribution.

\section{Steps of Analysis}

We start by comparing the relative income positions within all analyzed income components by ethnic group. In a first step, we focus on aggregates (market income, non-market income, taxes and social security contributions; Table 1a, 1b). In a second step, we split market and non-market income into the components mentioned above (Table 1b). After that, we calculate for each ethnic group: a) the population share receiving a specific income component (Table 2a), b) the most important income component (Table 2b), and c) the various income components as a share of total income (,,portfolio structure,; Table 2c). The final part of the descriptive analyses is based on the direct measurement of the re-distribution process. For each individual we calculate both indicators based on the difference of post- and pre-government income position; group-specific means and population shares, respectively, are presented in Figures 2a and $2 b$.

\footnotetext{
$20 \quad$ We categorize this type of old age pensions as private transfers, since they are explicitly not related to public
} transfers (c.f. Schwarze 1998). 
In order to control for eventual (pre-)retirement effects, all analyses are executed separately for the total population and those living in households with a head of prime age (20 to 60 years). ${ }^{21}$

In our multivariate analyses, we apply random-effects models (GLS regressions ${ }^{22}$ and probit models) controlling for various SES measures to analyze relative income positions based on pre-government (Column 1 of Tables 3a-3c) and post-government incomes (Column 2) as well as changes in the relative income position due to the re-distribution process within the tax and welfare system. With respect to the latter, we analyze the dimensions of wins and losses (changes in relative income position from pre- to post-government; Column 3) and identify winners and losers in an head count approach (Column 4). This provides us with information about which of the considered population groups on average are profiting from the tax and welfare system, and which of them are contributing to it.

Results of the regression models are given for the entire population (,,social burden approach,, in Table 3a), those living in households with a head of prime age (,labor market integration approach,, in Table $3 b)^{23}$, and those living in immigrants' households with a head of prime age (Table 3c), separately. This step of analysis is done in order to isolate the effect of ethnic origin as precise as possible. For that purpose, we control for year of observation, population density of place of living, employment structure of household members (metric unemployment index) ${ }^{24}$, household type, age, education, and health status of head of household, and --in case of immigrant-specific models-- date of immigration to Germany by terms of interaction (ethnic group * immigration date ${ }^{25}$ ). The latter is done to test whether assimilation, measured by duration of stay, has different impacts across ethnic groups. Means and standard deviations of all model variables are documented in Appendix Table A5.

\section{Empirical Results}

\section{IV.1 Descriptive Results}

\footnotetext{
21 Detailed information on the distribution of pre- and post-government income (quintiles, poverty measures) are presented in Appendix Tables A3a, A3b. The Appendix also contains information on population shares of ethnic groups (Table A1), typical immigration periods by ethnic groups (Table A2), and absolute means of equivalent pre- and postgovernment incomes by ethnic group (Table A4).

Breusch-Pagan Lagrange multiplier test results suggest that random effects models should be estimated rather than pooled regressions. Additionally, Hausman's specification test returned a significant result, which can be interpreted that the random effects and the regressors are correlated. Unfortunately, if using fixed effects models, we would lose insight into the effects of our most interesting variable, the ethnic group, because this variable remains unchanged for the vast majority of analyzed persons over this short period of observation. A methodologically unproblematic solution would be to accept a loss of information and just to analyze a single year of observation. However, the loss of cases would be substantial. We therefore decided to run random-effects models, keeping in mind, however, that the results should be interpreted with some caution.

23 Based on the regression estimates for the metric re-distribution measure (Column 3 in Tables 3a and 3b) we recalculate the information presented in Figure $2 b$ net of the impact of all considered SES information (Figure 3).

24 This index is calculated on the basis of employment information on the previous year across all household members of employable age: (number of months in unemployment/(number of months employed plus number of months in unemployment) $) * 100$.

25 Mean year of immigration of all immigrants in household.
} 
Relative Income Position in Various Types of Income

In a first step, we focus on pre-government (=market) income, non-market income, taxes and contributions, and finally, post-government income. The mean of each of these income types, based on the overall German distribution, is standardized to 100 . We then present relative positions in all of the income types for the population groups of interest. This gives a first hint about the economic performance of various ethnic groups (the underlying information on absolute values -- expressed in DM as of 1995 -- can be found in Appendix Table A4).

--- Table 1a about here ---

The upper panel of Table 1a shows the results based on the total population. In West Germany, the native-born German population has a somewhat higher market income than the German average $(+9 \%)$; the non-market income of this group is about that of the overall population living in Germany. As a consequence, the contribution of the native-born West German population to the tax and social security system is above average, too $(+9 \%)$, as well as the available post-government income $(+7 \%)$.

The market income of immigrants holds a medium position between native-born West Germans and East Germans, who have the lowest incomes. Among immigrants, however, there are remarkable differences between ethnic groups. Whereas especially the „pure,, Aussiedler have very low market incomes, people living in ,mixed,, households are even better off than the native-born West German population. ${ }^{26}$

All immigrant groups have substantially lower non-market incomes than the latter group (e.g. ,pure,, foreigners: $-43 \%)$, with one outstanding exception, the ,pure, Aussiedler (+15\%), who are on a similar level as East Germans $(+16 \%)$.

As in the group of the native-born West German population, the relative position with respect to contributions to the tax and social security system is almost identical to that with respect to the market income for all ethnic groups, which indicates a ,fair,, tax and social contribution system ${ }^{27}$.

\footnotetext{
26 A look at income distribution, inequality and poverty across ethnic groups reveals some additional information. The upper panel of Table A3a in the Appendix shows pre-government income quintiles based on the total population. Corresponding to their above average income position, both ,mixed,, immigrant groups also exhibit above average shares in the second highest and the highest quintiles. Especially „,mixed,, foreigners are substantially over-represented in the top quintile. East Germans are strongly under-represented in this top income group, but have no remarkable overrepresentation in lower quintiles, which results in a rather low income inequality. Worst off are ,pure,, immigrants with only less than $10 \%$ having top quintile equivalent incomes; at the same time, about $60 \%$ of incomes of these ethnic groups are concentrated in the lowest two quintiles. This pattern remains almost unchanged when focusing only on households with a head of prime age (lower panel of Table A3a).

27 Taxes and Social Security Contributions in the Equivalent Data File are the result of simulation procedures which
} 
Comparing market income and post-government income position, immigrants as a whole seem to be slightly worse off after re-distribution. This gives a first hint that immigrants in general at least do not economically „,burden,, the native-born population. The economically powerful „mixed,, groups of immigrants are those net paying most. Again, the group of ,pure,, Aussiedler is an exception being the only immigrant group profiting from re-distribution: they improve their relative income position from $66 \%$ of average pre-government income to $76 \%$ of average post-government income. ${ }^{28}$

Special attention needs to be given to East Germany. The average market income there is the same as that of ,pure,, foreigners in West Germany (21\% below population mean). However, in other income types we can observe substantial differences between those two groups. Compared to ,pure,, foreigner households in West Germany, non-market incomes in East Germany are substantially higher. In combination with the somewhat higher taxes and social security contributions paid by „pure, foreigners, this leads to remarkable differences in post-government income position (-27\% for ,pure, foreigners versus $-12 \%$ only for East Germans).

Summing up, it seems that „pure,, Aussiedler and East Germans are the two groups in Germany which on average are profiting most from non-market transfers, and these two groups are the only winners in the re-distribution process. Main net contributors to the system are the economically most successful groups of „mixed, ethnicity. Native-born West Germans do not change their income position substantially.

But this view, based on the entire population, is most likely heavily influenced by clear differences in the age structure of the ethnic groups under consideration. Nevertheless, looking at the results based only on persons living in households with a head of prime age (lower panel in Table 1a), the overall pattern remains pretty similar to the one found for the total population. However, there is one striking difference.

Concerning non-market income, the younger immigrants have a substantially higher relative income position than the older ones. This change is especially high in the group of ,pure,, foreigners (from $43 \%$ to $-2 \%$ ). The explanation for this result is described in more detail in the following section: lower eligibility and receipt of old age pensions, and high eligibility for other public transfers, e. g. unemployment benefits and social assistance, due to the weaker labor market position. However, it has to be pointed out that the relative position in non-market income of ,pure,, foreigners living in prime

take into account progression rules and basic allowances only (cf. Schwarze 1995); thus, they do not consider any additional allowances which otherwise might influence our results.

28 Regarding the distribution of post-government income (Table A3b in Appendix) we see both ,,pure,, immigrant groups to be highly concentrated at the lower end. Corresponding to this finding are very high poverty rates among these two immigrant groups, while ,mixed,, immigrants are in the most advantageous position. 
age headed households is still below the overall German average. This is mainly due to the very high relative position in non-market income recipiency among East Germans $(+40 \%$ versus $-12 \%$ for native-born Germans living in West Germany).

\section{Relative Income Position for Market and Non-market Income Components}

From the results presented in Table 1b, we get a deeper insight into differences between the groupspecific relative income positions only roughly described above.

--- Table $1 \mathrm{~b}$ about here ---

With respect to employment income, we find a corresponding situation to the total market income analyzed above. Within the total population (upper panel in Table 1b), the total of immigrants holds a middle position (-6\%) between native-born West Germans (+6\%) and East Germans (-16\%). Again, there are substantial differences between the immigrant groups. The best positions are held by the economically powerful „,mixed,, ethnic groups; worst off are „pure,, Aussiedler (-31\%).

As expected, capital income differs strongly between groups. The relative position of native-born West Germans (+26\%) is similar to that of the „,mixed,, groups. East Germans realize less than half the national average (-55\%), and the capital stock of ,pure,, foreigners is the lowest (-77\%).

Private Transfers from outside the household are concentrated on native-born West Germans $(+27 \%)$. With the exception of ,mixed,, Aussiedler, all immigrant groups have very low incomes from private transfers (on average -37\%). It is remarkable that East Germans have the lowest position in this income component $(-63 \%){ }^{29}$

Concerning non-market income components, we find most substantial differences across ethnic groups. Old age pensions are the highest among the ,pure,, German population, that is native-born West Germans, ,pure,, Aussiedler, and East Germans. The receipt of old age pension is the lowest in the foreigner groups, especially among ,pure,, foreigners $(-76 \%)^{30}$. The remarkable difference between old age pensions of Aussiedler and foreigners is clearly caused by institutional regulations which favor the former group because of their German citizenship (cf. Bundesminister für Arbeit und Sozialordnung 2000). While foreigners' pensions are calculated according to their actual working

\footnotetext{
$29 \quad$ Further analyses will show that this income component basically can be neglected (less than 2 percent of total portfolio).

When interpreting this result, however, one has to take into account that substantial transfers from the German old age pension system to re-migrated ,guest-workers,, exist. For example, in 1996 about 30,000 Turks living in their home country received old age pension payments from Germany worth 251.1 Million DM (BMA 2000a). This aspect can not be considered in our analysis.
} 
biography, those of Aussiedler are based on average careers in less-developed West German regions without necessarily having paid contributions.

With respect to our specific research motivation, public transfers (excluding old age pensions) are of special interest. Indeed, native-born West Germans have the lowest relative position in this income component $(-26 \%)$. This result is the main one driving the political discussion about burdens with respect to immigration. On average, immigrants have a relative position within this income component of $+26 \%$; among immigrants, the „pure,, foreigners are those with highest recipiency $(+43)$. This again is consistent with some crude arguments used in the political discussion. However, this result is only part of the story, as shown above in the discussion of the results of Table 1a. At least as remarkable is the extremely high relative public transfer position among East Germans $(+66 \%)$. In any case, this result can be driven by a variety of factors that are linked to public transfers: e.g. child benefits or unemployment compensation. This increases the need of multivariate analyses.

When focusing only on people living in households with a head of prime age (lower panel of Table 1b), again the principle structure of results remains fairly stable. Private transfers play now a bigger role within the ,pure,, immigrant groups and in East Germany, that is the groups with the weakest labor market positions. The relative income positions according to old age pensions now reflect different living arrangements across different ethnic groups: with the exception of „pure,, Aussiedler, all immigrant groups in prime age headed households have relative old age pension positions above those based on the total immigration. This means that immigrants of non-German nationality tend to live more often together with elder family members than people with German nationality do.

A remarkable result is given with respect to the public transfer recipiency among younger immigrants: whilst there is no age effect among native-born West and East Germans, the relative public transfers income position of younger immigrants $(+15 \%)$ is lower than that among the entire immigrant population $(+26 \%)$. This is due to effects within the foreigner groups, and may be important when thinking about steering immigration by law.

\section{Population Shares Receiving Specific Income Components and Paying Taxes and Contributions}

In this section, we analyze which ethnic groups receive specific income components, and which are paying taxes and contributions at all, that is regardless of the magnitude of income flows.

--- Table 2a about here --- 
Starting with the analysis for the total population (upper panel in Table 2a), we can state that the share of those not being fully dependent on old age pensions or public transfers is remarkably high. Among West and East German native-born citizens, almost all have access to at least one component of market income. $7 \%$ of immigrants have no access, this share being highest among ,pure,, Aussiedler $(12 \%)$

Due to different age composition, this pattern is reversed regarding employment income. Less than $80 \%$ of native-born Germans in West and East Germany receive employment income, but $85 \%$ of the immigrants. The only immigrant group with remarkable lower shares are again „pure,, Aussiedler $(74 \%)$.

In most ethnic groups, almost $90 \%$ of the respective population can rely on some capital income. The only exceptions are both ,pure,, immigrant groups (Aussiedler: 67\%, foreigners: 64\%). This is most likely the result of reduced opportunities to build up or accumulate stocks of wealth. Since this measure also includes imputed rents for owner occupiers, this results also reflects the rather high share of renters, especially those migrants who arrived most recently.

Private transfers are received by only $8 \%$ of the total German population. The lowest share can be found among East Germans and ,pure,, immigrants; the highest share among native-born West Germans (10\%), which also reflects their above average chances to receive old age pensions from their former firm or employer.

For all ethnic groups, the share of payers of taxes and contributions is pretty much in line with that of employment income recipients. The only remarkable point is that these two shares are exactly identical within the group of native-born West Germans, whereas in all other groups the share of tax and contributions payers is 2 to 4 percentage points lower than that of employment income recipients.

When focusing only on those people living in households with a head of prime age (lower panel in Table 2a), again the general pattern of results according to differences between ethnic groups remains almost unchanged.

Not surprisingly, the shares of those receiving market incomes is now even higher than in the total population and close to $100 \%$ in all groups. The most remarkable point in this respect is not differences, but similarities between groups. As expected, the shares of --in tendency younger-- people receiving employment or capital income are higher, and the shares of those receiving private transfers are lower compared with the total population. 
The reduction in the shares receiving non-market incomes is small, the highest within the group of native-born West Germans and the lowest in the total of immigration groups.

A most remarkable difference when switching from the total population results to those based on the younger population comes with public transfers. Whilst this share is 12 to 16 percentage points higher in all of the three ,pure,, German groups compared to the respective shares in the total population, the total of (younger) immigrants shows only a 5 percentage points increase compared to the share of total immigrants covering all age groups.

Nevertheless, among young immigrants as well as East Germans about $80 \%$ receive some public transfer while this share is less than 2/3 among young native born West Germans. Since the receipt of certain public benefits is not means tested (e.g. child benefits) but rather linked to specific sociodemographic characteristics, however, this is not an indicator for missing economic self-sustaining capability of immigrants per se. Rather a simultaneous control for social structure information and ethnic origin deems necessary.

Most Important Single Income Components

In a next step, we address the question which is the most important component of the income portfolios across the various ethnic groups.

--- Table $2 b$ about here ---

Focusing on the total population (upper panel of Table 2b) shows that employment income makes the most important (=highest) income component for about $70 \%$ of native-born West and East Germans. Consistent with previous results, this share is higher among immigrants (79\%). Once more, ,pure,, Aussiedler are a noticeable exception (66\%).

Capital income as the most important component is very rare in Germany. Not surprising, we find the highest share among native-born West Germans (4\%); in all other groups this share is $2 \%$ or lower. The share of people relying mainly on private transfers is even lower (less than $2 \%$ in all groups).

Old age pensions are the most important income component for one fifth of all native-born Germans, in West as well as in East Germany. This share is much lower among immigrants (11\%). However, the Aussiedler population makes a striking exception with shares of $15 \%$ for ,,mixed,, Aussiedler and even $23 \%$ for ,pure,, ones. Among foreigners this type of income rarely is the most important one, given the 
above mentioned household composition which sees elderly foreigners living in multi-generation households more often.

Public Transfers are the main income component for only $4 \%$ of native-born West Germans, but for 8\% among East Germans and immigrants to West Germany. Again, we can observe a strong heterogeneity among the immigrants: among the obviously positively selected ,,mixed,, immigrants, public transfers as the income component are even less common (2\%) in contrast to the „pure, immigrant groups ( $8 \%$ and $12 \%$, respectively).

Restricting the sample to households with a head of prime age (lower panel in Table 2b) yields just the expected results.

The share of those receiving employment income as the most important income component rises now close to $90 \%$. Again, we can observe the highest shares within the ,mixed,, groups of immigrants and the lowest among ,pure,, Aussiedler. The importance of capital income and private transfers as a highest income component remains very low.

The receipt of old age pensions in this age group is by definition of rather low importance across all considered subpopulations (between $2 \%$ and 5\%). The pattern concerning public transfer receipt remains the same as for the total population: public transfers are of higher importance among East Germans and ,pure,, immigrants (9\% to 11\%), of less importance for native-born West Germans (5\%), and of lowest importance for ,,mixed,, immigrants (2\%).

Although not fully comparable due to a somewhat different categorization of ethnic groups, data base, and period of time under consideration, our results with respect to the foreigners' groups are in line with those presented by Velling (1995, p. 153).

Income Components as a Share of Total Income

The results of the most comprehensive description of the income portfolio is given in Table 2c. For each individual, we relate components of market income, non-market income, and taxes and contributions to a standardized post-government income $(=100)$.

--- Table 2c about here --- 
Again, we first look at results based on the total population (upper panel in Table 2c). Concentrating on the totals of the three income aggregates, we find a very clear pattern: we observe two ethnic groups whose economic performance is clearly above average compared to the overall German situation (,mixed,, Aussiedler and „mixed,, foreigners), two groups with medium performance (nativeborn West Germans and ,pure,, foreigners), and two groups with low performance (East Germans and „pure,, Aussiedler).

The portfolio of the two groups with the best market performance (with „mixed,, foreigners being somewhat more successful than ,mixed,, Aussiedler) consists of $110 \%$ to $115 \%$ market income and $17 \%$ to $22 \%$ non-market income; deducting taxes (33\% in both groups) results in $100 \%$ of their individual portfolio. Among „,mixed,, Aussiedler, old age pensions play a somewhat greater role than among „mixed,, foreigners. This is compensated by a somewhat higher importance of employment income among ,mixed,, foreigners (102\%) compared to that of „mixed,, Aussiedler (98\%).

The income portfolio of the two groups with medium performance (with ,pure,, foreigners even being slightly better off than native-born West Germans) consists of $103 \%$ to $106 \%$ market income, about $25 \%$ non-market income, and is reduced by about $30 \%$ of taxes and contributions. Among native-born West Germans, capital income plays a greater role than within the group of ,pure,, foreigners (13\% versus 3\%). This is compensated by a much higher importance of employment income within the „pure, foreigners group (102\% versus $88 \%$ within the native-born West German group). A contradicting pattern between these two groups is also given for non-market income: whereas in the native-born West German group old age pensions contribute 19\% and public transfers only $7 \%$ to the income portfolio, this relation is reversed among ,pure,, foreigners.

The portfolio of the two groups with lowest performance (with ,pure,, Aussiedler having a somewhat worse position than East Germans) consists of $85 \%$ to $90 \%$ market income and 35\% to $38 \%$ nonmarket income. The deduction by taxes and contributions is only about $25 \%$ in both groups.

This clustering of groups according to their economic performance is clearly changed when focusing only on people living in households with prime age head (lower panel in Table 2c). The three clusters are now reduced to only two: on the one hand the economically better performing group, consisting of „mixed,, foreigners, „mixed,, Aussiedler, and native-born West Germans, and on the other hand „pure,, foreigners, ,pure,, Aussiedler, and East Germans building the less well performing cluster.

The income portfolio of the better performing cluster among the younger population consists of higher shares of market income (122\% to $124 \%$ ) and rather low shares of non-market income (12\% to $14 \%$ ); it is deducted by shares of taxes and contributions between $35 \%$ and $37 \%$. The proportions within the 
specific income components are remarkable similar. This result clearly confirms the expectation that immigrants tend to behave similar to native-born people, if assimilation has proceeded up to a certain level (in our analysis operationalized by the existence of at least one adult with German nationality in the household).

On the other hand, the cluster with lower performance among the younger population is much worse off. The income portfolio of these persons consists only of $107 \%$ to $110 \%$ market income, but includes $22 \%$ to $23 \%$ of non-market income; deduction by taxes and contributions by $30 \%$ to $32 \%$ make it $100 \%$ of the individual portfolio. As in the better performing cluster, the structure of sub-components of income is strikingly similar between the three groups. Disregarding the very special situation in East Germany, we can state that the low assimilation status of the two ,pure,, immigrant groups is a keystone in understanding the lower performance of these households. ${ }^{31}$

\section{Winners and Losers of Income Re-Distribution}

A straightforward way to define winners of income re-distribution is based on those individuals who improve their relative income position when moving from pre- to post-government income. Figure 2a shows the percentage share of winners for each ethnic group considered.

--- Figure 2a about here ---

In line with previous results based on the total population, we find more than half of East Germans and „pure,, Aussiedler to be relatively better off after re-distribution. Immigrants in general and „pure,, foreigners in particular are surprisingly similar to native-born West Germans (about $40 \%$ winners). Both ,mixed,, immigrant groups seem to profit the least from re-distribution (about 30\% winners). This picture is consistent with the findings concerning the very favorable position in the income distribution for these groups (Appendix Table A3a and A3b).

Reducing the population of interest to those who are living in households with prime age heads, in principle, shows the same structure on a lower level. However, the similarity between immigrants as a whole (33\% winners) and the West German autochthonous population (27\%) disappears. While it is obvious that this process is driven by differences in the age structure, it is up to a multiple regression to find out which other factors help to explain the remaining differences (see section IV.2).

$31 \quad$ For some more detailed information on the distribution of ethnic groups by immigration period see Appendix Table A2. Again, this argues for the need of multiple regression models in order to find out if there is a significant assimilation effect once we control for other SES information. 
This head count approach does not take into account the magnitude of wins or losses in the course of the re-distribution effects. Thus, we add a metric measure given by the individual difference of postand pre-government income position. Figure $2 \mathrm{~b}$ shows the mean of these individual differences for each ethnic group. ${ }^{32}$

--- Figure $2 b$ about here ---

Again, based on the total population ,pure,, Aussiedler and East Germans are clear winners of redistribution, improving their relative income position on average by about 10 percentage points. All other groups are on average financing this process, though it is again ,,mixed,, immigrants who pay the most.

Based on the prime aged population, the picture changes more than probably expected from the previous descriptive findings (in Table 1a), where the differences between the group-specific mean income positions appeared to be rather small. According to our individual metric re-distribution measure, all ethnic groups are -- on average -- contributing to the re-distribution process. However, principle inter-group differences remain: ,pure,, immigrant groups as well as East Germans on average lose 5 to 8 percentage points, only, while ,,mixed,, immigrant groups as well as native born West Germans are major financiers (-18 to -20 percentage points).

\footnotetext{
$32 \quad$ Note that results based on this new piece of information do not necessarily coincide with previous results concerning a comparison of average pre- and post-government income positions (see Table 1a). This new variable is the mean of individual differences, and as such it is very sensitive to bigger individual changes from pre- to post-government income: on the one hand these changes are caused by the progressive tax system, on the other hand by the old age pension system. While these effects are less important when comparing means of pre- and post-government income (as shown in Table 1a), the new measure reacts most sensitive. This is especially true when looking at the younger population only, since this clearly reduces the above mentioned impact of the old age pension system.
} 


\section{IV.2 Results from Random-Effects Models}

In our multivariate analysis, we try to isolate the effect of ethnic origin by controlling for various SES measures. As dependent variables, we use the natural logarithm of the relative pre-government income position (1st columns in Tables 3a-3c), the natural logarithm of the relative post-government income position (2nd columns in Tables 3a-3c), the individual difference between the relative postgovernment income position and the relative pre-government income position to identify gains and losses of the income re-distribution process (3rd columns in Tables 3a-3c), and finally, the sign of the previously described variable to identify winners and losers of re-distribution within a head count approach (4th columns in Tables 3a-3c). The first three columns report results gained from randomeffects GLS regressions, the fourth ones are based on random-effects probit models.

Income Positions and Re-Distribution Effects Among the Total Population

As a first step, we again base our analysis on the total population (Table 3a).

--- Table 3a about here ---

Focusing on pre-government income and controlling for important individual and household characteristics (column I), we can state that people living in „mixed,, immigrant households have similar income positions as the reference group of native-born West Germans: while the income of „mixed,, Aussiedler do not significantly differ from those of the reference group, „mixed,, foreigners show a very small, but statistically significant lower position. „Pure,, foreigners have a substantially lower position as do East Germans. The lowest position is observed for „pure,, Aussiedler, which indicates that this group ceteris paribus is economically weaker than the reference group of native born West Germans, even after controlling for all the other SES information.

The effects found for the control variables are as expected. The highest equivalent incomes are earned by couples without children. Singles have lower incomes as well as couples with kids; the incomes for the latter groups continuously decrease with increasing number of children. In the context of household composition, the worst income position is observed for single parents. The income rises with the age of the head of household; this effect being reversed for elderly people. The higher the education of the head of household, the higher the income. A bad health status of the head of household lowers the income position, as well as unemployment affection of the adult members of the household. Market incomes are lower in metropolitan areas, and real wages decreased over the observed period. Basically, the results (structure and statistical significance) for these control variables 
remain very stable for the different model specifications. For this reason, we concentrate on variables identifying ethnic groups when interpreting the results of the following regression models.

The estimation results for post-government income (column II) are in line with those presented above, though basically all coefficients are somewhat smaller in absolute terms. This is due to the levelling effect of taxation on the one hand and public transfers receipt on the other hand. ${ }^{33}$

However, the magnitude of the re-distribution effects shows big differences between the various ethnic groups (column III). Compared to native-born West Germans, „mixed,, Aussiedler neither profit nor lose from this re-distribution process. Foreigners are net payers, especially the „mixed,, ones. East Germans and ,pure,, Aussiedler are substantially profiting from the re-distribution process; they both improve their relative income position from pre- to post-government income on average by 8 percentage points. Turning to a head count approach (column IV), this pattern does not change very much $^{34}$.

The message to keep in mind from this analysis is that foreigners are contributing above average to the support of the weakest ethnic groups in Germany, both of them of German nationality: „pure, Aussiedler and East Germans. In other words: with respect to the pure fact of not having a German passport, foreigners as a whole (,,pure,, and „,mixed,, households) are not burdening the German tax and social security system. In contrast, their relative contribution to that system is the highest among all ethnic groups in Germany. In addition, it should be noted that concerning the group of economically rather weak ,pure,, foreigners, a common principle of progressive tax systems seems to be violated: in contrast to other groups with low pre-government income like „pure,, Aussiedler and East Germans they do not profit from the re-distribution process.

\section{Income Positions and Re-distribution Effects Among the Younger Population}

In a next step, we restrict our sample to persons living in households with a head of prime age (Table $3 b)$. The structure of the research design remains the same as in the preceding section.

--- Table $3 b$ about here ---

\footnotetext{
33 It is also necessary to consider that the overall explanatory power of this model is clearly reduced when comparing the results to those attained for pre-government income (adjusted $\mathrm{R}^{2}=.50$ and .32 , respectively). This is not surprising, since most of our control variables (e.g. education) are typically better suited for explaining variation in market income.

34 The only remarkable point is that more people among the „pure,, foreigners are losers of the re-distribution than among the „mixed,, foreigners. In light of the different picture found in column III, this means that there are some few most successful ,mixed,, foreigners paying high amounts of taxes and contributions.
} 
The results for the younger population are pretty much in line with expectation, i.e. most changes -when compared to the results for the total population (Table 3a) -- seem to be related to the ageselection imposed. Both types of „mixed,, immigrant groups are economically as strong as native born West Germans, given that even after controlling for education, etc. we do not find any significant differences in the respective pre-government income positions (column I). However, „mixed, foreigners show a somewhat reduced post-government income position (column II). Based on the „,metric approach,, younger „pure,, foreigners are c.p. no longer net payers to the re-distribution process (column III); although the results of the head count approach (column IV) still suggest that a significant proportion among this group is losing from re-distribution. However, already wellassimilated „mixed,, foreigners again are paying significantly higher net amounts to the re-distribution process than native-born West Germans do. As was found for the total population, younger East Germans and „pure,, Aussiedler are profiting substantially from the re-distribution process. Concerning the head count results (column IV), there is no change from the all age population analysis to the prime age restricted one: „Pure,, foreigners run a high risk to lose in the re-distribution process, this risk being somewhat lower for „,mixed,, foreigners, whereas East Germans and „pure,, Aussiedler have good chances to profit from it.

Applying the regressions estimates (Columns 3 of Tables $3 a$ and $3 b$ ) to an average observation (individual in households) we re-calculate the metric contribution to the tax and welfare system for each ethnic group after controlling for a variety of SES measures (Figure 3). Figure $2 b$ presented the corresponding results based on pure descriptive findings for these groups, i.e. without controlling for other social structure information. Thus, any change in the results from Figure $2 b$ to Figure 3 for $a$ given ethnic group is driven by between-group differences in social structure.

--- Figure 3 about here ---

In principle, the overall pattern in both figures is fairly similar. However, there are two most remarkable findings. First, concerning the total population, the severe re-distribution losses among the „mixed,, immigrant groups are now strongly reduced (from $-15 \%$ to -6 percentage points for „mixed, Aussiedler and from $-9 \%$ to -2 percentage points for ,mixed,, foreigners, respectively). Secondly, when focusing only on the younger population, the net contribution position of ,pure, foreigners changes from $-8 \%$ to -17 percentage points. This indicates that the social structure of „mixed, immigrants is highly above average and that of young ,pure,, foreigners is highly below average with respect to the entire population of Germany. This result changes especially the recognition of the redistribution performance of younger ,,pure, foreigners: when controlling for differences in socioeconomic measures, now both foreigner groups (as well as „,mixed,, Aussiedler) show a similar 
behavior in the re-distribution process as the native-born West Germans. Younger ,pure,, Aussiedler as well as East Germans, however, still are contributing to a much lower degree.

\section{Income Positions and Re-distribution Effects Among Immigrants}

Finally, we restrict our sample to immigrants living in households with a head of prime age only (Table 3c). This is done to avoid misinterpretations caused by „untypical,, correlations between covariates and dependent variables when pooling immigrants and native-born (West and East) Germans. In addition, this gives us a better insight into the specific economic performance between immigrant groups. The only change in the modeling --compared to the previous steps of analysis-- is the inclusion of another relevant control variable, the time period of immigration. This variable is controlled for each ethnic group separately, e.g. we use interaction terms for immigration status and immigration cohort. The reference group is now made up by ,pure,, foreigners who immigrated before 1981. This group consists to a great extent of migrant workers from Mediterranean countries (,guestworkers"). ${ }^{35}$

--- Table 3c about here ---

With respect to pre-government income (Column I), we find --in tendency-- a positive effect of duration of residence in Germany for all ethnic groups. With the exception of „mixed“ foreigners who seem to assimilate very fast, other ethnic groups immigrated after 1990 show substantial lower incomes than the reference category of early immigrated guest workers; the loss is highest for recently immigrated „pure“ foreigners. Among those groups with longer duration of stay, the „pure“ groups with in tendency poor assimilation show similar (low) incomes, and both „mixed“ groups perform significantly better. Therefore, both indicators for assimilation (,,mixed“ vs. ,poor“ and duration of stay in Germany) simultaneously show the positive correlation between assimilation and labor market success. Combined with the observed differences across ethnic groups, these results are in line with those found by Winkelmann and Winkelmann (1998) for New Zealand. In addition, the negative effect found for „born in Germany, (,second generation,,) signals that this characteristic per se is not an indicator for perfect societal integration. These persons are worse off compared to „pure“ foreigners with early immigration date. The effects found for the other control variables show a mostly similar pattern than those for the total prime age population including West and East Germans. This is at least remarkable with respect to the positive effect of higher education on market income, which could give a hint for formulating an efficient immigration steering law -- if politically desired. In principle, the results for post-government income (Column II) are in line with those presented for pre-government

35 See Appendix Table A2 and A5 for detailed information on the distribution of immigration periods by ethnic group. 
income. As was the case in the previous analyses (Tables 3a,b) post government income distribution shows smaller differences between the ethnic groups without leveling them completely.

Column III shows that all ethnic groups living in Germany for a long time have similar positions in the redistribution process; an exception is made by the economically most successful „,mixed“ foreigners who contribute above average. When compared to the reference group of long-term resident guestworkers this population contributes significantly more already after short duration of stay in Germany. Those who immigrated in most recent years profit more from re-distribution than first generation immigrants; this is clearly less coined for „mixed“ immigrant household. „Pure“ foreigners who moved to Germany during the 1980s do not differ from the reference group: this important finding shows that the „burden“ effect rapidly decreases with longer duration of stay. Again, „pure“ Aussiedler make an exception: This is the only group profiting more from redistribution than early immigrants even after having spent a substantial period of time in Germany (immigration period 1981 - 1990). Interestingly, those foreigners born in Germany lose more in the re-distribution process than early immigrants.

The general pattern of results remains when focusing on re-distribution winners in a head count approach (Column IV): Again, as expected, across all ethnic groups the chance of profiting from the re-distribution process is increasing the shorter the period of residence in Germany. In line with the quantitative approach above, we find an outlying position for ,pure“ Aussiedler with medium duration of stay. These persons exhibit a re-distribution behavior comparable to persons of same ethnic origin who most recently immigrated. On the other hand, foreigners born in Germany ceteris paribus have the highest risk to be net contributors to the re-distribution process. This means that this specific group -when controlling for other SES measures-- is the one who economically „,burdens,, the autochthonous population the least among all immigrant groups. This again is an important message when talking about the follow-up costs of immigration to Germany.

\section{Summary and Conclusions}

In this paper, we test the widespread prejudice that immigrants as an entire group are an economic burden to German society. This prejudice is nourished by the uncontested facts that immigrants in general show a weaker labor market position and have higher shares of welfare take-ups.

In our analysis, we take into account the heterogeneity of immigrants to Germany by differentiating three indicators of assimilation and integration. Based on the typical German concept of ethnicity and citizenship, we first distinguish Ethnic Migrants, who are granted German citizenship when 
immigrating from former Eastern Block Countries to Germany by constitutional law (Aussiedler), from other immigrants (i.e. foreigners). Secondly, we use information on household composition as an indicator for qualified assimilation: ,mixed,, immigrant households (at least one adult household member is a native-born German) are contrasted with ,pure,, immigrant households. Finally, we also consider time spent in Germany since date of immigration. This innovative form of clustering allows a better understanding of the relation between the assimilation process and the economic performance of immigrants.

Based on descriptive results, we find -- with respect to market-income as the main indicator for economic performance -- that the relative income position of immigrants takes a middle position between the more successful native-born West Germans and the less successful East Germans. However, immigrants show a most heterogeneous behavior: ,mixed,, immigrants have an even better position than native-born West Germans. This result is in line with that of Dustmann (1996) who reports that marriage to a non-German partner slows down the integration process of immigrants. „Pure,, foreigners perform similar to East Germans. „Pure,, Aussiedler are by far worst off, i. e. show the lowest degree of self-supporting capacities.

The well-known lower economic performance of the total group of immigrants as compared to that of the native-born (West) German population drives the public debate about the social burden caused by immigration. This neglects our second important finding: immigrants' receipt of non-market income, consisting of old age pensions and public transfers, is --with the exception of the group of ,pure, Aussiedler-- much lower than that of the native-born (West) Germans. This also reflects the clear differences in the age structure between the ethnic groups. In addition, and this is our third important result, we can observe that immigrants on average --again with the exception of ,pure,, Aussiedler-are the losers in the re-distribution process from pre- to post-government incomes. Whereas nativeborn West Germans only lose slightly, immigrants help finance the re-distribution gains allocated to „pure, Aussiedler and East Germans. This result is mainly due to the fact that non-German immigrants include a smaller group of persons eligible for old age pensions. As a consequence, we state that (at least up to now) immigrants with non-German nationality on average are not burdening German society, but, on the contrary, are net contributors to the German tax and social security system. This finding is in line with that of previous studies by LaLonde and Topel (1991), Rürup and Sesselmeier (1994), Simon (1996), and Weber and Straubhaar (1996).

The income portfolio analysis exhibits three clusters of ethnic groups: the portfolio of „mixed, immigrant groups shows a most favorable structure with high shares of market income and below average shares of non-market income, which is similar to the structure of native-born West Germans income portfolio. „Pure,, foreigners hold a medium position, whereas „pure,, Aussiedler and East 
Germans show unfavorable portfolio structures with high shares of non-market income, especially concerning public transfers. When focusing only on the younger population of households with heads of prime age, these three clusters turn into two, consisting of native-born West Germans and both „mixed,, immigrant groups with favorable portfolios on the one hand and East Germans and both „pure,, immigrant groups with unfavorable portfolio structures on the other hand.

We then apply multiple regression models (random-effects GLS and random-effects Probits) in order to control simultaneously for potential socio-economic differences between various population subgroups. The results clearly show that immigrants of non-German nationality lose in the redistribution process, whereas ,pure,, Aussiedler and East Germans strongly profit from it. This result holds when restricting the sample to persons living in younger households. In addition, we can show that the contribution to the re-distribution process among immigrants on average increases with duration of stay in Germany.

With respect to market income as well as post-government income, young immigrants in general have a less favorable income position and portfolio structure than native born West Germans. However, our results show that the quality of this structure clearly improves with increasing duration of residence in Germany and especially when ,proving,, an advanced assimilation by living together with an (adult) native-born German. A most remarkable result is that immigrants as a whole are not burdening the German tax and social security system. A very specific exception is given for „pure,, Aussiedler. The outstandingly favorable position of this group in the re-distribution process -- as well as that of the East German population -- seems to be caused by political considerations rather than other effects within a ,normal,, assimilation process. Finally, the multivariate analyses show that a non-German nationality per se does not create a risk factor with respect to the „burden,, aspect, and that all ethnic groups (with the exception of „pure“ Aussiedler) in tendency have a highly comfortable situation in the redistribution process only for a short period after immigration. These findings could become most relevant when thinking about the drafting of a future German immigration law.

We conclude by admitting some shortcomings of our analysis. Due to data limitations, we could not take into account old age pension receipt of re-migrated foreigners who spend the eve of life in their home countries. Considering this aspect might affect our results in such a way that the net contribution of non-German immigrants would be reduced. In addition, we could not include those public expenditures related to immigration which are not directly related to individual households. These costs --if above average, compared to expenditures specifically concentrated on the autochthonous population-- would affect our interpretation, too. Furthermore, our analysis has a static character. „Immigration has a far-reaching and long-lasting impact,, (Borjas 1994, p. 1713). It is not our ambition to forecast the economic consequences of future developments, like those influenced by 
intergenerational transmissions in educational behavior and changes in social structure of immigrant cohorts. With respect to the social security system, e.g., the old age pension system, the interdependent effects of various demographic parameters are the most complex (Schmähl 1995) ${ }^{36}$.

Further research should try to internalize those aspects, especially when done with regard to giving advice for immigration politics; however, the methodological problems seem to be almost insurmountable in this respect. Beyond these reservations, we believe that our results are valid enough to defeat the common prejudice that the existing population of immigrants in Germany is burdening the economic system.

36 In general, the limitations explicitly listed in Weber and Straubhaar (1996, p. 351) affect the interpretation of our results as well. 


\section{References}

Axelsson, Roger and Westerlund, Olle 1998: A panel study of migration, self-selection and household real income. In: Journal of Population Economics 11(1): 113-126

Baker, Michael and Benjamin, Dwayne 1995: The receipt of transfer payments by immigrants to Canada. In: The journal of human resources 30 (4): 650-676

Bauer, Thomas K. 1997: Do immigrants reduce natives' wages? Evidence from Germany. Munich: Ludwig Maximilians University, Dept. of Economics, Discussion Paper No. 1997/05

Bauer, Thomas K. 1998: Arbeitsmarkteffekte der Migration und Einwanderungspolitik. Eine Analyse fuer die Bundesrepublik Deutschland. Heidelberg

Bauer, Thomas K. and Zimmermann, Klaus F. 1997: Unemployment and wages of ethnic Germans. In: Quarterly Review of Economics and Finance (37): 361-377

Bauer, Thomas K. and Zimmermann, Klaus F. 1999: Occupational Mobility of Ethnic Migrants. Bonn: Institute for the Study of Labor, IZA Discussion Paper No. 58

Bird, Edward J., Kayser, Hilke, Frick, Joachim R., and Wagner, Gert G. 1999: the Immigrant Welfare Effect: Take-Up or Eligibility? Bonn: Institute for the Study of Labor, IZA Discussion Paper No. 66

Birg, Herwig 1995: Globale und nationale demographische Entwicklung und Wanderungen als Rahmenbedingungen für die sozialen Sicherungssysteme in Deutschland. In: Zeitschrift für die gesamte Versicherungswissenschaft 84 (4) 593-616

Börsch-Supan, Axel H. 1994: Migration, social security systems, and public finance. In: Siebert, Horst (Ed.): Migration: A challenge for Europe. Symposium 1993. Tübingen, 119-142

Borjas, George Jesus 1985: Assimilation, Changes in Cohort Quality, and the Earnings of Immigrants. In: Journal of labor economics 3 (4): 463-489

Borjas, George Jesus 1994: The economics of immigration. In: The journal of economic literature 32 (4): 1667-1717

Borjas, George Jesus 1995a: Assimilation and changes in cohort quality revisited. What happened to immigrant earnings in the 1980s? In: Journal of labor economics 13 (2): 201-245

Borjas, George Jesus 1995b: Immigration and welfare: 1970 - 1990. In: Research in labor economics 14: $253-282$

Borjas, George Jesus and Hilton, Lynette 1996: Immigration and the welfare state. Immigrant participation in means-tested entitlement programs. In: The quarterly journal of economics 111 (2): 575-604

Borjas, George Jesus and Trejo, Stephen J. 1991: Immigrant participation in the welfare system. In: Industrial \& labor relations review 44 (2): 195-211

Borjas, George Jesus and Trejo, Stephen J. 1993: National origin and immigrant welfare recipiency. In: Journal of public economics 50 (3): 325-344

Büchel, Felix, Frick, Joachim R. and Voges, Wolfgang 1997: Der Sozialhilfebezug von Zuwanderern in Westdeutschland. In: Kölner Zeitschrift für Soziologie und Sozialpsychologie 49 (2): 272-290

Büchel, Felix and Wagner, Gert 1996: Soziale Differenzen der Bildungschancen in Westdeutschland Unter besonderer Berücksichtigung von Zuwandererkindern. In: Zapf, Wolfgang, Schupp, Jürgen and Habich, Roland (Eds.): Lebenslagen im Wandel. Frankfurt/Main and New York: 80-96 
Bundesministerium für Arbeit (BMA) 2000: Fremdrentenrecht. http://bma.de -> „Rentenversicherung,,.,accessed 25 January 2000.

Bundesministerium für Arbeit (BMA) 2000a: Fremdrentenrecht. http://bma.de -> „Maßnahmen des Bundesministeriums für Arbeit und Sozialordnung zur sozialen und beruflichen Integration von türkischen Arbeitnehmern und ihren Familienangehörigen (1990-1998),,.,accessed 25 January 2000.

Bundesregierung der BRD 1996: Situation der Bundesrepublik Deutschland als Einwanderungsland. Antwort der Bundesregierung auf die Große Anfrage ... In : Verhandlungen des Deutschen Bundestages. Drucksache 13/2990. Bonn: 1-67

Burkhauser, Richard V., Butrica, Barbara A., Daly, Mary C. 2000: The PSID-GSOEP Equivalent File: A Product of Cross-National Research. In: Voges, Wolfgang (Ed.): Dynamic Approaches to Comparative Social Research: Recent Developments and Applications. Aldershot, UK: 5366 (in press)

Burkhauser, Richard V., Kreyenfeld, Michaela, and Wagner, Gert G. 1997: The German SocioEconomic Panel Study: A Representative Sample of Reunified Germany and its Parts. In: In: DIW-Vierteljahrshefte zur Wirtschaftsforschung 66(1): 7-16.

Chiswick, Barry R. and Miller, Paul W. 1994: The determinants of post-immigration investments in education. In: Economics of education review 13 (2): 163-177

DeNew, John P. and Zimmermann, Klaus F. 1994: Native wage impacts of foreign labor. A random effects panel analysis. In: Journal of population economics 7 (2): 177-192

Dicke, Hugo and Glismann, Hans Hinrich 1995: Migration: The welfare calculus of immigrant countries. In: Jahrbücher für Nationalökonomie und Statistik 214 (3): 342-357

Dietz, Barbara 1999: Ethnic German Immigration from Eastern Europe and the former Soviet Union to Germany - The Effects of Migrant Networks. Bonn: Institute for the Study of Labor, IZA Discussion Paper No. 68

Dunn, Thomas A., Kreyenfeld, Michaela, and Lovely, Mary Elizabeth 1997: Communist human capital in a capitalist labor market : the experience of East German and ethnic German immigrants to West Germany. In: Dunn, Thomas A. and Schwarze, Johannes (Eds.): Proceedings of the 1996 Second International Conference of the German Socio-Economic Panels Study Users. Special Issue of Vierteljahrshefte zur Wirtschaftsforschung 66 (1): 151158

Dustmann, Christian 1996: The social assimilation of immigrants. In: Journal of population economics 9 (1): $37-54$

Felderer, Bernhard 1994a: Can immigration policy help to stabilize social security systems? In: Giersch, Helmut (Ed.): Economic aspects of international migration. Berlin etc.: 197-226

Felderer, Bernhard 1994b: Immigration, the labor market, and structural adjustment - The case of Germany. In: Siebert, Horst (Ed.): Migration: A challenge for Europe. Symposium 1993. Tübingen: 71-84

Fielding, Anthony J. 1995: Migration and social change: A longitudinal study of the social mobility of 'immigrants' in England and Wales. In: European journal of population 11 (2): 107-121

Frick, Joachim, Büchel, Felix, and Krause, Peter 2000: Public Transfers, Income Distribution, and Poverty in Germany and the United States. In: Becker, Irene and Hauser, Richard (Eds.): The personal distribution of income in an international perspective. Heidelberg etc. (in press)

Frick, Joachim R., Büchel, Felix, Krause, Peter, and Wagner, Gert G. (1997): Immigration has Increased Income Inequality and Poverty in Germany Slightly. In: Economic Bulletin 34(2): 25-32. 
Frick, Joachim R., Smeeding, Timothy M, and Wagner, Gert G. 1999: Immigrants in Two Modern Nations: Characteristics of the Foreign and Native Born Populations in Germany and the United States. In: Dunn, Thomas A., Frick, Joachim R., and Witte, James C. (Eds.): Proceedings of the 1998 Third International Conference of the German Socio-Economic Panel Study Users. Sonderheft der Vierteljahrshefte zur Wirtschaftsforschung, Vol. 68 (2): 297-307

Gang, Ira N. and Rivera-Batiz, Francisco L. 1994: Labor market effects of immigration in the United States and Europe: substitution vs. complementarity. In: Journal of population economics 7 (2): $157-175$

Gang, Ira N and Zimmermann, Klaus F. 1999: Is Child like Parent? Educational Attainment and Ethnic Origin. Bonn: Institute for the Study of Labor, IZA Discussion Paper No. 57

Göbel-Zimmermann, Ralph und Masuch, Thorsten 1998: Regelungsbedarf fuer eine Einwanderungsgesetzgebung? In: Zeitschrift fuer Rechtspolitik 31 (11): 435-441;

Grabka, Markus M., Schwarze, Johannes, and Wagner, Gert G. 1999: How unification and immigration affected the German income distribution. In: European Economic Review 43: 867-878

Gustman, Alan L. and Steinmeier, Thomas Lee 1998: Social security benefits of immigrants and US born. Cambridge, MA: NBER Working Paper 6478

Gusy, Christoph 1994: Kriterien für eine Einwanderungspolitik der Bundesrepublik und der EG. In: Weidenfeld, Werner, Hönekopp, Elmar, Konle-Seidl, Regina, and Institut fuer Arbeitsmarktund Berufsforschung (Eds.): Europäische Integration und Arbeitsmarkt. Nuremberg: 223239

Gusy, Christoph and Ziegler, Katja 1997: Regelungsmöglichkeiten für eine europäische Einwanderungsgesetzgebung. In: Weber, Albrecht (Ed.): Einwanderungsland Bundesrepublik Deutschland in der Europäischen Union: Gestaltungsauftrag und Regelungsmöglichkeiten? Osnabrück: 331-344

Hailbronner, Kay 1992: Citizenship and Nationhood in Germany. In: Brubaker, W. (Ed.): The Politics of Citizenship in France and Germany. Cambridge, UK: 67-79.

Haisken-DeNew, John P., Büchel, Felix, and Wagner, Gert G. 1997: Assimilation and other determinants of school attainment in Germany - Do immigrant children perform as well as Germans? In: Dunn, Thomas A. and Schwarze, Johannes (Eds.): Proceedings of the 1996 Second International Conference of the German Socio-Economic Panels Study Users. Special Issue of Vierteljahrshefte zur Wirtschaftsforschung 66 (1): 169-179

Hatton, Timothy J. and Williamson, Jeffrey Gale (Eds.) 1994: Migration and the international labor market, 1850 - 1939. London

Helberger, Christof, Rendtel, Ulrich, and Schwarze, Johannes 1994: Labor market entry of young people analyzed by a double threshold model. In: Schwarze, Johannes, Buttler, Friedrich, and Wagner, Gert G. (Eds.): Labour Market Dynamics in Present Day Germany. Boulder, Colorado: 142-164.

Hof, Bernd 1996: Szenarien künftiger Zuwanderungen und ihre Auswirkungen auf Bevölkerungsstruktur, Arbeitsmarkt und soziale Sicherung. In: Allgemeines statistisches Archiv 80 (1): 109-145

Hu, Wei-yin 1998: Elderly immigrants on welfare. In: The journal of human resources 33 (3): 711741 ;

Jensen, Leif I. 1988: Patterns of immigration and public assistance utilization, 1970 - 1980. In: International migration review 22 (1): 51-83 
Khoo, Siew-ean 1994: Correlates of welfare dependency among immigrants in Australia. In: International migration review 28 (1): 68-92

Koller, Barbara 1997: Aussiedler der großen Zuwanderungswellen, was ist aus ihnen geworden? Die Eingliederungssituation von Aussiedlerinnen und Aussiedlern auf dem Arbeitsmarkt in Deutschland. In: Mitteilungen aus der Arbeitsmarkt- und Berufsforschung 30 (4): 766-789

Lederer, Harald W., Rau, Roland, and Rühl, Stefan 1999: Migrationsbericht 1999. Zu- und Abwanderung nach und aus Deutschland. (Im Auftrag der Beauftragten der Bundesregierung für Ausländerfragen). Bonn

LaLonde, Robert J. and Topel, Robert H. 1991: Immigrants in the American labor market - Quality, assimilation, and distributional effects. In: The American economic review 81 (2): 297-302

Licht, Georg and Steiner, Viktor 1994: Assimilation, labour market experience and earnings profiles of temporary and permanent immigrant workers in Germany. In: International review of applied economics 8 (2): 130-156

Lohrmann, Reinhard 1997: International migration dynamics and immigration policy in Europe - An international perspective. In: Weber, Albrecht (Ed.): Einwanderungsland Bundesrepublik Deutschland in der Europäischen Union: Gestaltungsauftrag und Regelungsmöglichkeiten. Osnabrück: $31-43$

Maani, Sholeh A. 1993: Immigrants and the use of government transfer payments. In: The Australian economic review 104: 65-76

Müller, Tobias 1995: Immigration, distribution des revenus et bien-etre social. In: Schweizerische Zeitschrift für Volkswirtschaft und Statistik. 131 (3): 517-533

Pischke, Jörn-Steffen and Velling, Johannes 1997: Employment effects of immigration to Germany An analysis based on local labor markets. In: The review of economics and statistics 79 (4): 594-604

Projektgruppe SOEP 1995: Das Sozio-oekonomische Panel (SOEP) im Jahre 1994. In: DIWVierteljahrshefte zur Wirtschaftsforschung 64(1): 5-15.

Reitz, Jeffrey G. 1998: Warmth of the welcome - The social causes of economic success for immigrants in different nations and cities. Boulder, Colorado

Reitz, Jeffrey G.; Frick, Joachim R.; Calabrese, Tony und Wagner, Gert G. 1999: The Institutional Framework of Ethnic Employment Disadvantage: A Comparison of Germany and Canada. In: Journal of Ethnic and Migration Studies, 25 (3): 397-444.

Riphahn, Regina T. 1998: Immigrant participation in the German welfare program. In: Finanzarchiv. 55 (2): $163-185$

Rotte, Ralph 1998: Sorties from the fortress - The current system of anti-immigration policies in Germany. Bonn: Institute for the Study of Labor, IZA Discussion Paper No. 13

Rürup, Bert and Sesselmeier, Werner 1994: Zu den wichtigsten Auswirkungen von Einwanderung auf Arbeitsmarkt und Sozialversicherungen. In: Klose, Hans-Ulrich (Ed.): Zuwanderung: Möglichkeiten und Grenzen. Series Forum Demographie und Politik, Vol. 5: 64-89

Schmähl, Winfried 1994: Wird das Sozialsystem eines alternden Deutschlands Einwanderer brauchen? In: Kuhn, Barbara E. (Ed.): Einwanderung und Wohlstand. Munich: 80-87

Schmähl, Winfried 1995: Alterung der Bevölkerung, Mortalität, Morbidität, Zuwanderung und ihre Bedeutung fuer die gesetzliche Rentenversicherung - Auswirkungen, Handlungsbedarf und Handlungsmoeglichkeiten. In: Zeitschrift fuer die gesamte Versicherungswissenschaft 84 (4): 617-646 
Schmidt, Christoph Matthias 1993: The earnings dynamics of immigrant labour: London: CEPR Discussion Paper No. 763

Schmidt, Christoph Matthias 1997: Immigrant performance in Germany : labor earnings of ethnic German migrants and foreign guest-workers. In: The quarterly review of economics and finance (Special Issue): 379-397

Schmidt, Peter and Weick, Stefan 1998: Starke Zunahme von Kontakten und Ehen zwischen Deutschen und Ausländern. In: ZUMA-Informationsdienst Soziale Indikatoren ISI 19: 1-5.

Scholten, Ulrich and Thum, Marcel 1996: Public pensions and immigration policy in a democracy. In: Public choice 87 (3/4): 347-361

Schultz, Theodore Paul 1998: Immigrant quality and assimilation - A review of the US literature. In: Journal of population economics 11 (2): 239-252

Schwarze, Johannes 1995: Simulating German Income and Social Security Tax Payments Using the GSOEP. Syracuse University, Syracuse, NY: Cross-National Studies in Ageing Project Paper No. 19.

Schwarze, Johannes 1998: Der Einfluß alternativer Konzeptionen von Alterssicherungssystemen auf Sicherungsniveau, Altersarmut und Einkommensverteilung: Ein Vergleich zwischen Deutschland und den USA. In: Hauser, Richard (Ed.): Alternative Konzeptionen der Sozialen Sicherung. Vol. 265 des Vereins für Socialpolitik. Berlin: 127-168.

Seifert, Wolfgang 1997: Integration of "old" and "new" immigrant groups in Germany. In: Dunn, Thomas A. and Schwarze, Johannes (Eds.): Proceedings of the 1996 Second International Conference of the German Socio-Economic Panels Study Users. Special Issue of Vierteljahrshefte zur Wirtschaftsforschung 66 (1): 159 - 168

Simon, Julian L. 1994: On the Economic Consequences of Immigration: Lessons for Immigration Policies. In: Giersch, Helmut (Ed.): Economic aspects of international migration. Berlin etc.: 227-248

Simon, Julian L. 1996: Public expenditures on immigrants to the United States, past and present In: Population and development review 22 (1) 99-109

Sinn, Hans-Werner 1997: The value of children and immigrants in a pay-as-you-go pension system : a proposal for a partial transition to a funded system. Cambridge, MA: NBER Working Paper No. 6229

Sommer, Bettina and Voit, Hermann 1999: Bevölkerungsentwicklung 1998. Wirtschaft und Statistik, $11,851-857$

Ulrich, Ralf E. 1994a: Foreigners and the social insurance system in Germany. In: Steinmann, Gunter and Ulrich, Ralf E. (Eds.): The economic consequences of immigration to Germany. Heidelberg: 61-80

Ulrich, Ralf E. 1994b: "Vertriebene" and "Aussiedler" - the immigration of ethnic Germans In: Steinmann, Gunter and Ulrich, Ralf E. (Eds.): The economic consequences of immigration to Germany. Heidelberg: $155-177$

United States/ House/ Committee on Economic and Educational Opportunitites: Field hearing on public benefits, employment, and immigration reform. Hearing before the Committee on Economic and Educational Opportunities, House of Representatives, One Hundred Fourth Congress, second session, hearing held in San Diego, CA, February 22, 1996. Washington

United Nations Population Division 2000: Replacement Migration: Is it a Solution to Declining and Ageing Populations? http://www.undp.org/popin/wdtrends/replamigration.htm, accessed 25. January 2000. 
Velling, Johannes 1995: Immigration und Arbeitsmarkt. Eine empirische Analyse für die Bundesrepublik Deutschland. Baden-Baden

Voges, Wolfgang, Frick, Joachim R., and Büchel, Felix 1998: The Integration of Immigrants into West German Society - The Impact of Social Assistance. In: Kurthen, Hermann, Fijalkowski, Jürgen and Wagner, Gert G. (Eds.): Immigration, Citizenship, and the Welfare State in Germany and the United States - Part A, Vol. 14 (A) of Immigrant Incorporation, Industrial Development and Social Fabric Series von JAI Press Inc., Stamford/Connecticut und London: $159-174$

Wagner, Gert G., Burkhauser, Richard V., and Behringer, Friederike 1993: The English Language Public Use File of the German Socio-Economic Panel Study. In: Journal of Human Resources 28(2): 429-433.

Weber, Rene and Straubhaar, Thomas 1996: Immigration and the public transfer system - Some empirical evidence for Switzerland. In: Weltwirtschaftliches Archiv 132 (2): 330-355

Wellisch, Dietmar and Wildasin, David Earl 1996: Dezentrale Umverteilung und Einwanderung. In: Ifo-Studien 42 (1): 101-133

Winkelmann, Liliana and Winkelmann, Rainer 1998: The labour market outcomes of New Zealand's old and new immigrants: Christchurch, New Zealand: Univ. of Canterbury, Dep. of Economics, Discussion Paper No. 9806

Winter-Ebmer, Rudolf and Zweimüller, Josef 1996: Immigration and the earnings of young native workers. In: Oxford economic papers 48 (3): 473-491

Witzsch, Günter 1999: Zuwanderungsbeschränkungen durch Einwanderungsgesetz? In: Zeitschrift fuer Rechtspolitik 32 (1): 10-18

Wollenschläger, Michael 1995: Grundzüge eines europäischen Einwanderungskonzeptes. In: Forschungsinstitut der Friedrich-Ebert-Stiftung, Abt. Arbeits- und Sozialforschung (Hg.): Europäische Einwanderungspolitik. Series „Gesprächskreis Arbeit und Soziales, No. 45. Bonn: 45-58

Wollenschläger, Michael 1997: Rechtlicher Rahmen und Voraussetzungen einer Zuwanderungsgesetzgebung. In: Weber, Albrecht (Ed.): Einwanderungsland Bundesrepublik Deutschland in der Europäischen Union - Gestaltungsauftrag und Regelungsmöglichkeiten. Osnabrück: 197-224

Zameck, Walburga von 1993: Einwanderungsland Deutschland - Ökonomische Konsequenzen und wirtschaftspolitische Optionen. In: Jahrbuch fuer Sozialwissenschaft 44 (3): 348-364

Zavodny, Madeline 1997: Welfare and the locational choices of new immigrants. In: Economic review (Federal Reserve Bank of Dallas) 2: 2-10

Zimmermann, Klaus F. 1994a: Immigration policies in Europe - An overview. In: Siebert, Horst (Ed.): Migration - A challenge for Europe. Symposium 1993. Tübingen: 227-258

Zimmermann, Klaus F. 1994b: Some General Lessons for Europe's Migration Problem. In: Giersch, Helmut (Ed.): Economic aspects of international migration. Berlin etc.: 249-273

Zimmermann, Klaus F. 1995: Tackling the European migration problem. In: The journal of economic perspectives 9 (2): 45-62

Zimmermann, Klaus F. 1999: Ethnic Germans Migration Since 1989 - Results and Perspectives. Bonn: Institute for the Study of Labor, IZA Discussion Paper No. 50 
Table 1a: $\quad$ Relative Income Position in Various Types of Income in Germany, 1995-1997' by Ethnic Group

Total Population of Persons in Private Households

\begin{tabular}{|c|c|c|c|c|c|c|c|c|}
\hline \multirow[b]{2}{*}{ Type of Income } & \multicolumn{6}{|c|}{ West Germany } & \multirow{2}{*}{$\begin{array}{c}\text { East } \\
\text { Germany } \\
\text { Total }\end{array}$} & \multirow{2}{*}{$\begin{array}{c}\text { Germany } \\
\text { Total }\end{array}$} \\
\hline & $\begin{array}{l}\text { Native } \\
\text { Born } \\
\text { German }\end{array}$ & Total & $\begin{array}{l}\text { „Pure, } \\
\text { Aussiedler }\end{array}$ & $\begin{array}{l}\text { Immigrants } \\
\text { „Mixed,, } \\
\text { Aussiedler }\end{array}$ & $\begin{array}{l}\text { „Pure, } \\
\text { Foreigners }\end{array}$ & $\begin{array}{l}\text { „Mixed,, } \\
\text { Foreigners }\end{array}$ & & \\
\hline $\begin{array}{l}\text { Pre-Government } \\
\text { (=Market) Income }\end{array}$ & 109 & 90 & 66 & 118 & 79 & 126 & 79 & 100 \\
\hline $\begin{array}{l}\text { Non-Market Income } \\
\text { (Pensions and Public } \\
\text { Transfers) }\end{array}$ & 102 & 74 & 115 & 84 & 57 & 60 & 116 & 100 \\
\hline $\begin{array}{l}\text { Taxes and Social } \\
\text { Security Contributions }\end{array}$ & 109 & 92 & 67 & 122 & 81 & 125 & 77 & 100 \\
\hline $\begin{array}{l}\text { Post-Government } \\
\text { Income }\end{array}$ & 107 & 86 & 76 & 109 & 73 & 112 & 88 & 100 \\
\hline
\end{tabular}

Persons in Private Households with Head of Prime Age

\begin{tabular}{|c|c|c|c|c|c|c|c|c|}
\hline \multirow[b]{2}{*}{ Type of Income } & \multicolumn{6}{|c|}{ West Germany } & \multirow{2}{*}{$\begin{array}{c}\text { East } \\
\text { Germany } \\
\text { Total }\end{array}$} & \multirow{2}{*}{$\begin{array}{c}\text { Germany } \\
\text { Total }\end{array}$} \\
\hline & $\begin{array}{l}\text { Native } \\
\text { Born } \\
\text { German }\end{array}$ & Total & $\begin{array}{l}\text { „Pure, } \\
\text { Aussiedler }\end{array}$ & $\begin{array}{l}\text { Immigrants } \\
\text { „Mixed,, } \\
\text { Aussiedler }\end{array}$ & $\begin{array}{l}\text { „Pure, } \\
\text { Foreigners }\end{array}$ & $\begin{array}{l}\text { „Mixed, } \\
\text { Foreigners }\end{array}$ & & \\
\hline $\begin{array}{l}\text { Pre-Government } \\
\text { (=Market) Income }\end{array}$ & 110 & 84 & 70 & 112 & 70 & 115 & 81 & 100 \\
\hline $\begin{array}{l}\text { Non-Market Income } \\
\text { (Pensions and Public } \\
\text { Transfers) }\end{array}$ & 88 & 99 & 115 & 109 & 98 & 77 & 140 & 100 \\
\hline $\begin{array}{l}\text { Taxes and Social } \\
\text { Security Contributions }\end{array}$ & 111 & 85 & 71 & 115 & 71 & 112 & 79 & 100 \\
\hline $\begin{array}{l}\text { Post-Government } \\
\text { Income }\end{array}$ & 107 & 86 & 74 & 111 & 73 & 112 & 89 & 100 \\
\hline
\end{tabular}

1) Average of 1994-1996 income years.

Source: SOEP; PSID-GSOEP Equivalent Data File; authors' calculation. 
Table 1b: $\quad$ Relative Income Position for Market- and Non-Market Income Components in Germany, 1995-1997', by Ethnic Group

Total Population of Persons in Private Households

\begin{tabular}{|c|c|c|c|c|c|c|c|c|}
\hline \multirow[b]{2}{*}{ Income Components } & \multicolumn{6}{|c|}{ West Germany } & \multirow{2}{*}{$\begin{array}{c}\text { East } \\
\text { Germany } \\
\text { Total }\end{array}$} & \multirow{2}{*}{$\begin{array}{c}\text { Germany } \\
\text { Total }\end{array}$} \\
\hline & $\begin{array}{l}\text { Native } \\
\text { Born } \\
\text { German }\end{array}$ & Total & $\begin{array}{c}\text { „Pure, } \\
\text { Aussiedler }\end{array}$ & $\begin{array}{l}\text { Immigrants } \\
\text { „Mixed, } \\
\text { Aussiedler }\end{array}$ & $\begin{array}{c}\text { „Pure, } \\
\text { Foreigners }\end{array}$ & $\begin{array}{l}\text { „Mixed,, } \\
\text { Foreigners }\end{array}$ & & \\
\hline \multicolumn{9}{|l|}{$\begin{array}{l}\text { Pre-Government } \\
\text { (=Market) Income }\end{array}$} \\
\hline $\begin{array}{l}\text { Employment } \\
\text { Income }\end{array}$ & 106 & 94 & 69 & 119 & 86 & 127 & 84 & 100 \\
\hline . Capital Income & 126 & 59 & 42 & 113 & 23 & 131 & 45 & 100 \\
\hline - $\quad$ Private Transfers & 127 & 63 & 60 & 106 & 51 & 66 & 37 & 100 \\
\hline \multicolumn{9}{|l|}{ Non-Market Income } \\
\hline - Old Age Pensions & 112 & 53 & 109 & 78 & 24 & 45 & 98 & 100 \\
\hline - $\quad$ Public Transfers & 74 & 126 & 131 & 97 & 143 & 98 & 166 & 100 \\
\hline
\end{tabular}

$\underline{\text { Persons in Private Households with Head of Prime Age }}$

\begin{tabular}{|c|c|c|c|c|c|c|c|c|}
\hline \multirow[b]{2}{*}{ Income Components } & \multicolumn{6}{|c|}{ West Germany } & \multirow{2}{*}{$\begin{array}{c}\text { East } \\
\text { Germany } \\
\text { Total }\end{array}$} & \multirow{2}{*}{$\begin{array}{c}\text { Germany } \\
\text { Total }\end{array}$} \\
\hline & $\begin{array}{l}\text { Native } \\
\text { Born } \\
\text { German }\end{array}$ & Total & $\begin{array}{c}\text { „Pure, } \\
\text { Aussiedler }\end{array}$ & $\begin{array}{c}\text { Immigrants } \\
\text { „Mixed, } \\
\text { Aussiedler }\end{array}$ & $\begin{array}{c}\text { „Pure,, } \\
\text { Foreigners }\end{array}$ & $\begin{array}{c}\text { „Mixed,, } \\
\text { Foreigners }\end{array}$ & & \\
\hline \multicolumn{9}{|l|}{$\begin{array}{l}\text { Pre-Government } \\
\text { (=Market) Income }\end{array}$} \\
\hline $\begin{array}{l}\text { Employment } \\
\text { Income }\end{array}$ & 108 & 87 & 73 & 112 & 75 & 114 & 85 & 100 \\
\hline . Capital Income & 127 & 60 & 38 & 120 & 23 & 135 & 47 & 100 \\
\hline - $\quad$ Private Transfers & 121 & 75 & 92 & 86 & 72 & 57 & 53 & 100 \\
\hline \multicolumn{9}{|l|}{ Non-Market Income } \\
\hline . Old Age Pensions & 107 & 72 & 79 & 130 & 59 & 60 & 101 & 100 \\
\hline - Public Transfers & 76 & 115 & 139 & 95 & 122 & 88 & 165 & 100 \\
\hline
\end{tabular}

1) Average of 1994-1996 income years.

Source: SOEP; PSID-GSOEP Equivalent Data File; authors’' calculation. 
Table 2a: Components and Structure of Equivalent Post-Government Income in Germany, 1995-1997'), by Ethnic Group:

Population Share Receiving Income Component (in \%)

Total Population of Persons in Private Households

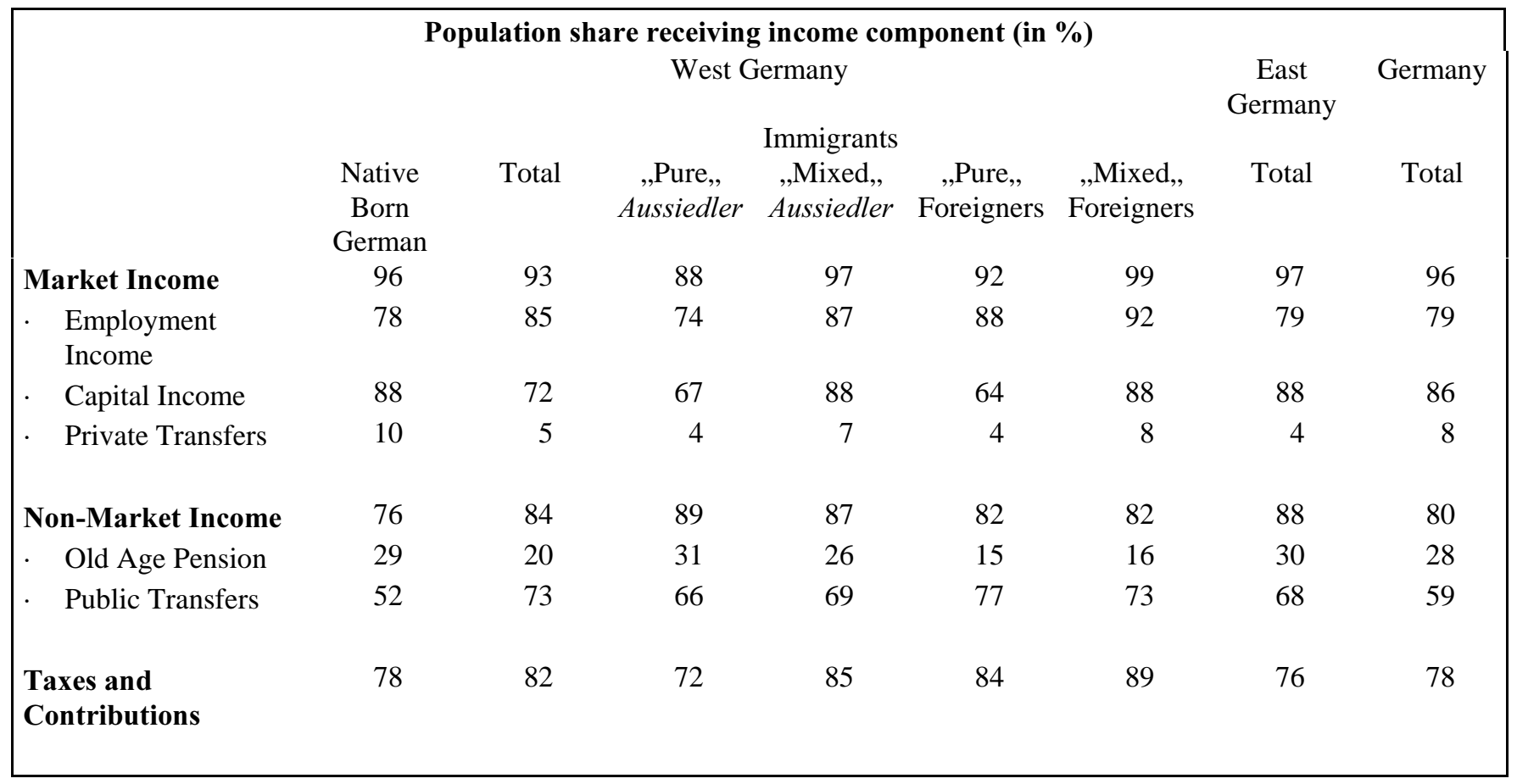

Persons in Private Households with Head of Prime Age

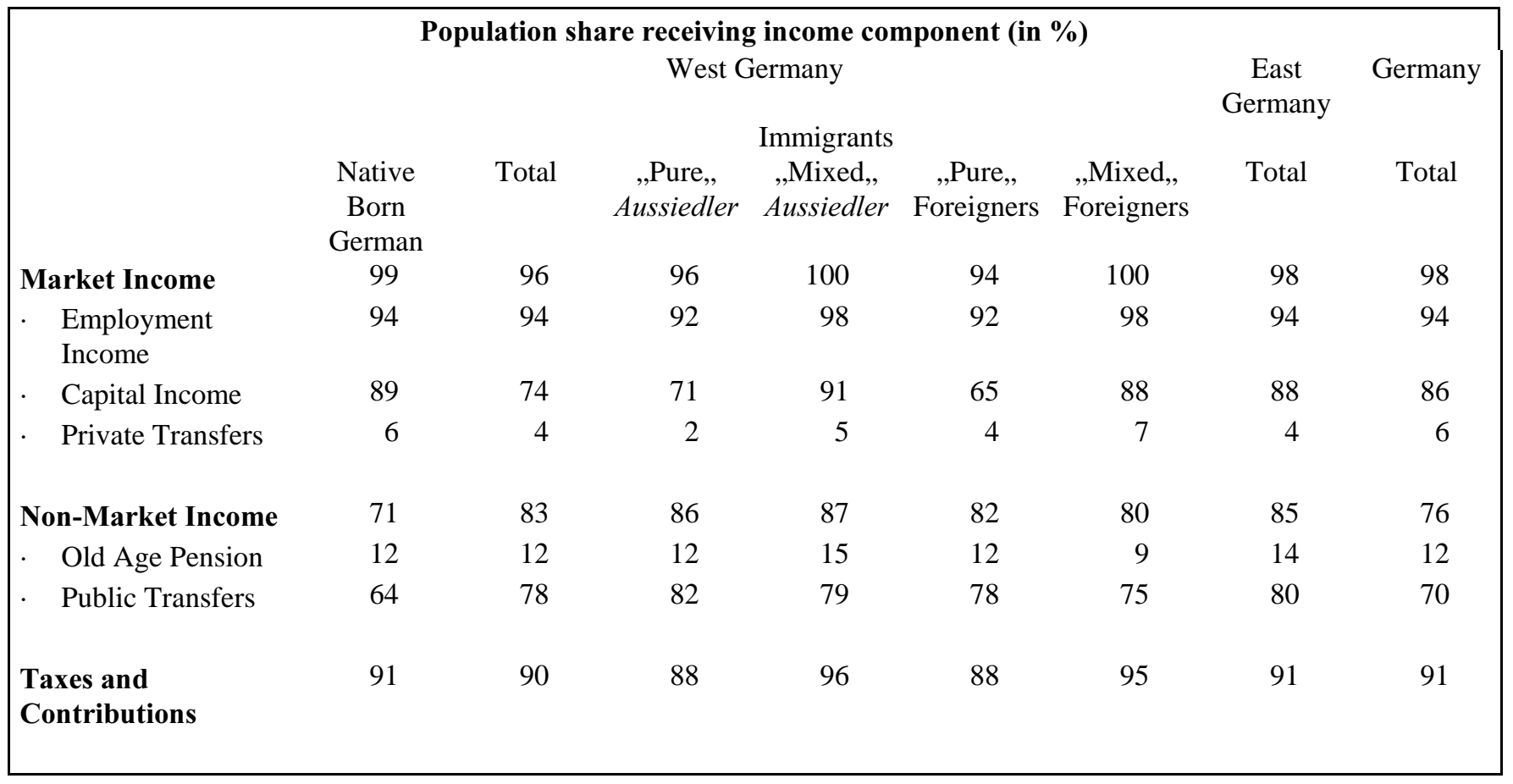

1) Average of 1994-1996 income years.

Source: SOEP; PSID-GSOEP Equivalent Data File; authors' calculation. 
Table 2b: Components and Structure of Equivalent Post-Government Income in Germany, 1995-1997'), by Ethnic Group:

Most Important Single Income Component (in \%)

Total Population of Persons in Private Households

\begin{tabular}{|c|c|c|c|c|c|c|c|c|}
\hline \multicolumn{9}{|c|}{ Most important single income component (in \%) } \\
\hline & \multicolumn{6}{|c|}{ West Germany } & \multirow{2}{*}{$\begin{array}{c}\text { East } \\
\text { Germany } \\
\text { Total }\end{array}$} & \multirow{2}{*}{$\begin{array}{c}\text { Germany } \\
\text { Total }\end{array}$} \\
\hline & $\begin{array}{l}\text { Native } \\
\text { Born } \\
\text { German }\end{array}$ & Total & $\begin{array}{l}\text { „Pure, } \\
\text { Aussiedler }\end{array}$ & $\begin{array}{l}\text { Immigrants } \\
\text { „Mixed,, } \\
\text { Aussiedler }\end{array}$ & $\begin{array}{l}\text { „Pure, } \\
\text { Foreigners }\end{array}$ & $\begin{array}{l}\text { „Mixed, } \\
\text { Foreigners }\end{array}$ & & \\
\hline \multicolumn{9}{|l|}{ Market Income } \\
\hline $\begin{array}{l}\text { Employment } \\
\text { Income }\end{array}$ & 72 & 79 & 66 & 81 & 82 & 88 & 71 & 73 \\
\hline Capital Income & 4 & 1 & 2 & 2 & 0 & 1 & 1 & 3 \\
\hline Private Transfers & 1 & 1 & 1 & 0 & 1 & 0 & 0 & 1 \\
\hline \multicolumn{9}{|l|}{ Non-Market Income } \\
\hline . Old Age Pension & 20 & 11 & 23 & 15 & 5 & 9 & 20 & 19 \\
\hline - Public Transfers & 4 & 8 & 8 & 2 & 12 & 2 & 8 & 5 \\
\hline Total & 100 & 100 & 100 & 100 & 100 & 100 & 100 & 100 \\
\hline
\end{tabular}

Persons in Private Households with Head of Prime Age

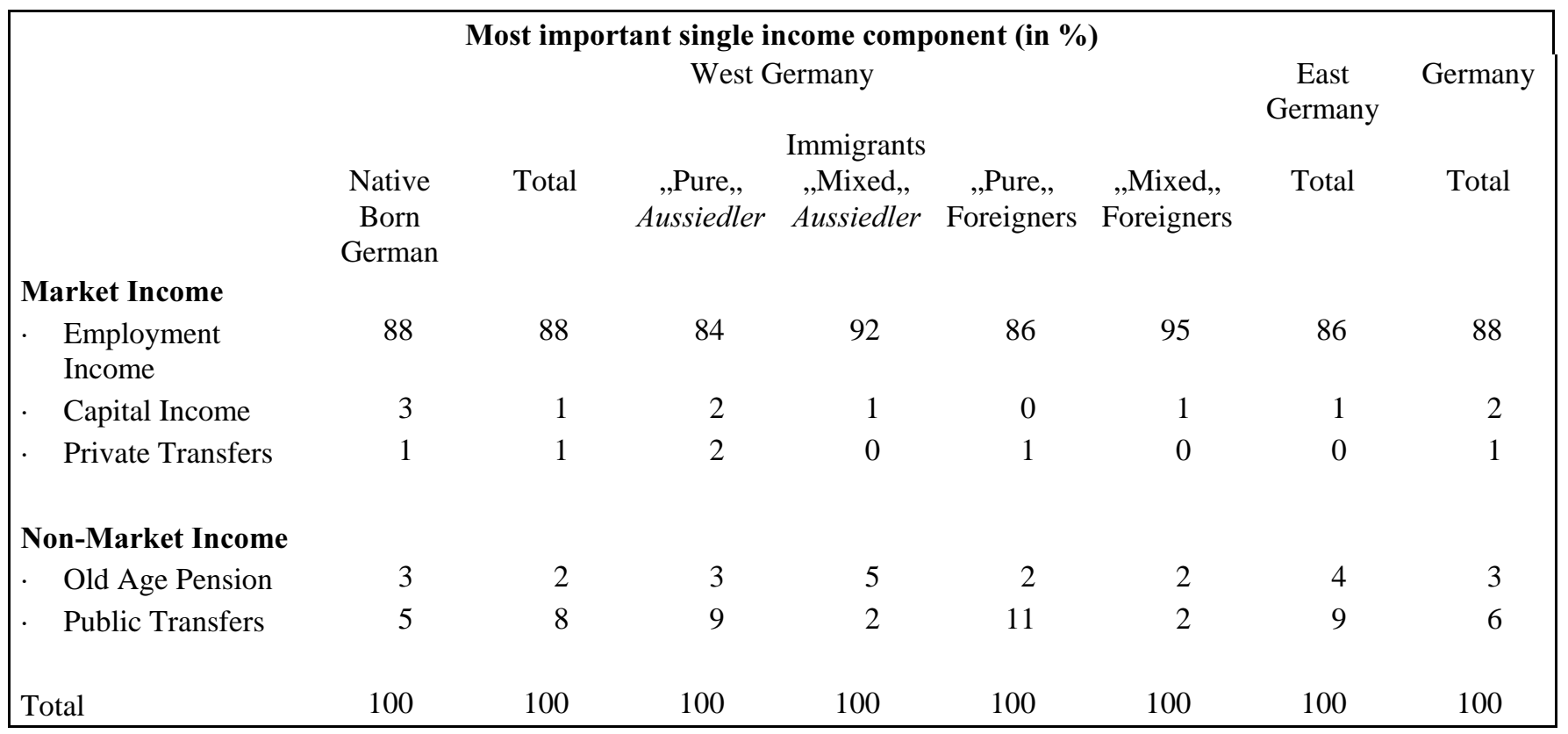

1) Average of 1994-1996 income years.

Source: SOEP; PSID-GSOEP Equivalent Data File; authors’ calculation. 
Table 2c: Components and Structure of Equivalent Post-Government Income in Germany, 1995-1997'1), by Ethnic Group:

Income Components as a Share of Total Income (in \%)

$\underline{\text { Total Population of Persons in Private Households }}$

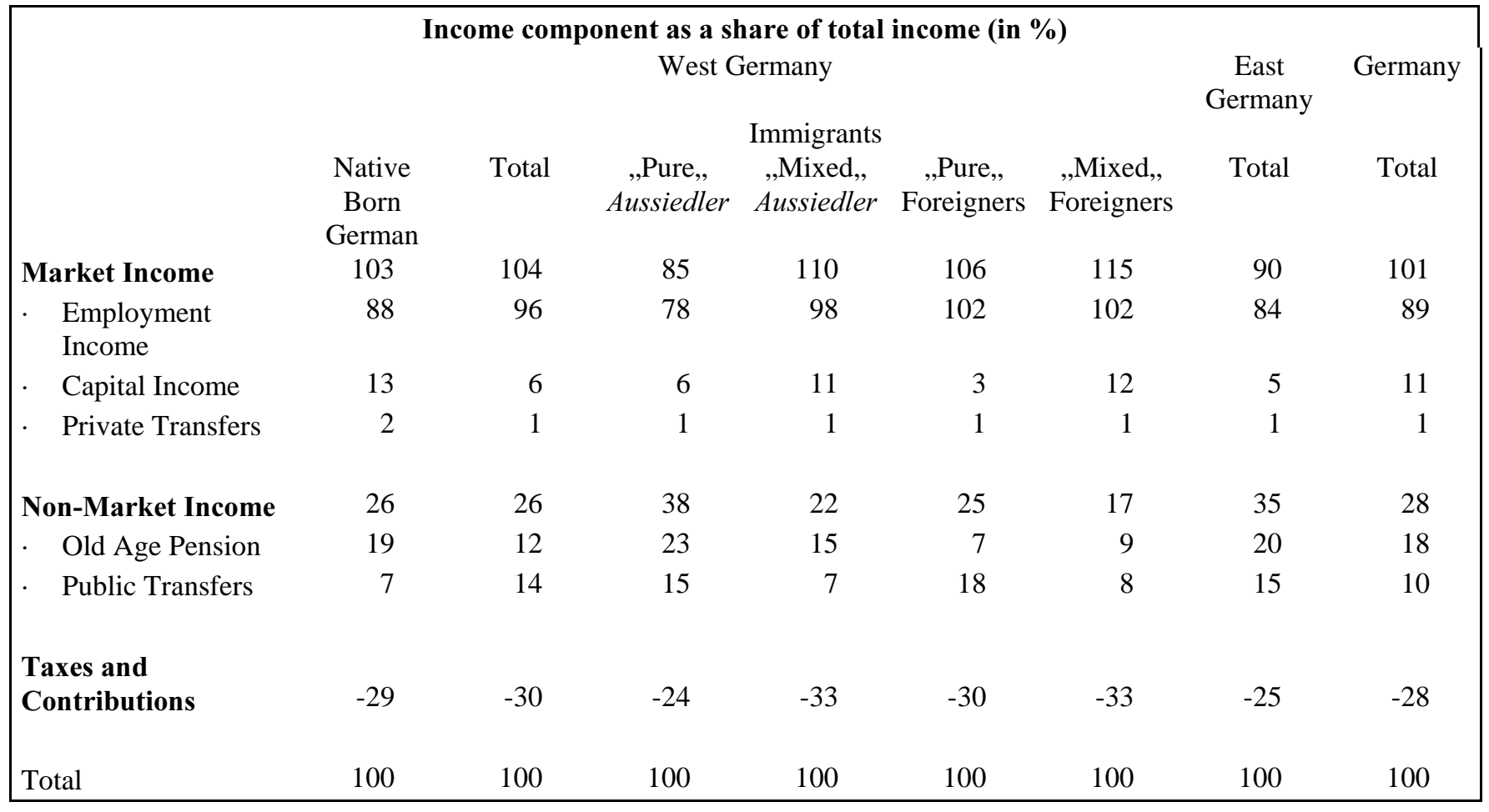

Persons in Private Households with Head of Prime Age

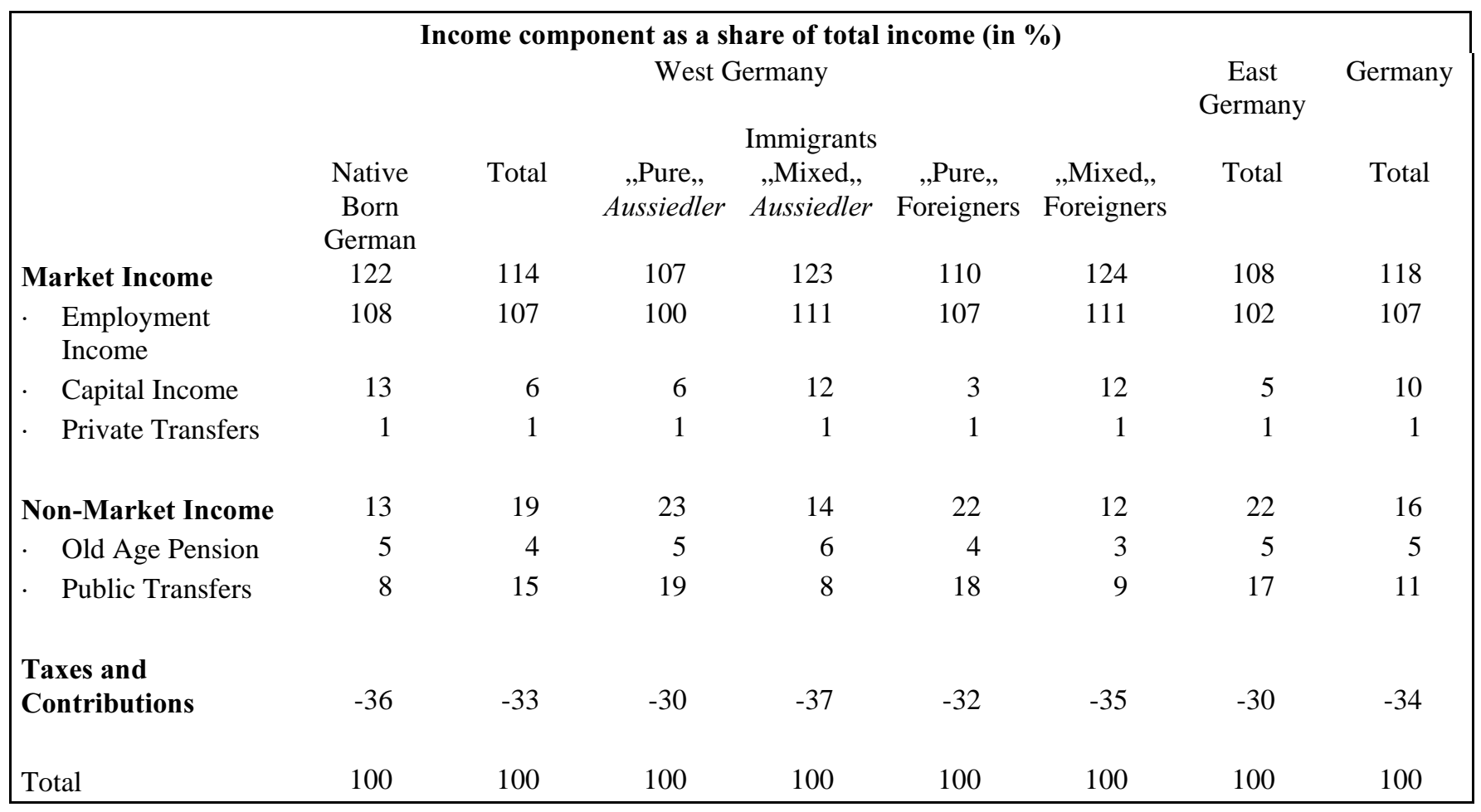

1) Average of 1994-1996 income years.

Source: SOEP; PSID-GSOEP Equivalent Data File; authors’ calculation. 
Table 3a: $\quad$ Effects on Relative Income Positions and Redistribution Effects in Germany, 1995-1997 ${ }^{1)}$ : Results from Random-Effects GLS Regression and Probit Models, - Total Population -

\begin{tabular}{|c|c|c|c|c|}
\hline & In (Relative & ne Position) & & \\
\hline Variable & & & Absolute change in & Positive change \\
\hline & Pre-Gov’t & Post-Gov't & Income Position & due to \\
\hline & Income & Income & due to & Redistribution \\
\hline & & & Redistribution & (1=yes) \\
\hline „Pure,, Aussiedler & $-.567 * *$ & $-.314 * *$ & $8.082 * *$ & $.693 * *$ \\
\hline & $(.031)$ & $(.013)$ & $(.988)$ & $(.083)$ \\
\hline „Mixed,, Aussiedler & -.063 & -.022 & .290 & -.165 \\
\hline & $(.044)$ & $(.018)$ & $(1.362)$ & $(.124)$ \\
\hline „Pure, , Foreigner & $-.263 * *$ & $-.247 * *$ & $-1.002+$ & $-.410 * *$ \\
\hline & $(.019)$ & $(.008)$ & $(.607)$ & $(.051)$ \\
\hline „Mixed,, Foreigner & $-.074 *$ & $-.035 * *$ & $-3.760 * *$ & $-.275 * *$ \\
\hline & $(.031)$ & $(.013)$ & $(.955)$ & $(.087)$ \\
\hline East Germany & $-.391 * *$ & $-.148 * *$ & $7.956 * *$ & $.611 * *$ \\
\hline & $(.015)$ & $(.006)$ & $(.487)$ & $(.043)$ \\
\hline Single & $-.437 * *$ & $-.240 * *$ & $-1.180+$ & .114 \\
\hline & $(.021)$ & $(.008)$ & $(.622)$ & $(.072)$ \\
\hline Couple, 1 child & $-.043 * *$ & $-.061 * *$ & $6.439 * *$ & $.463 * *$ \\
\hline & $(.016)$ & $(.006)$ & $(.466)$ & $(.050)$ \\
\hline Couple, 2 children & $-.252 * *$ & $-.172 * *$ & $11.862 * *$ & $.964 * *$ \\
\hline & $(.017)$ & $(.007)$ & $(.517)$ & $(.054)$ \\
\hline Couple, 3 and more children & $-.522 * *$ & $-.248 * *$ & $19.740 * *$ & $2.204 * *$ \\
\hline & $(.022)$ & $(.009)$ & $(.665)$ & $(.067)$ \\
\hline Single-Parent & $-.664 * *$ & $-.333 * *$ & $12.139 * *$ & $1.436 * *$ \\
\hline & $(.022)$ & $(.009)$ & $(.658)$ & $(.068)$ \\
\hline Other Type of Household & $.172 * *$ & $.061 * *$ & $1.233 *$ & $.399 * *$ \\
\hline & $(.016)$ & $(.006)$ & $(.486)$ & $(.050)$ \\
\hline Age (Head of Household) & $.121 * *$ & $.025 * *$ & $-3.924 * *$ & $-.440 * *$ \\
\hline & $(.002)$ & $(.001)$ & $(.067)$ & $(.010)$ \\
\hline$\left(\right.$ Age $\left.^{* * 2}\right) / 100$ (Head of Household) & $-.152 * *$ & $-.022 * *$ & $5.001 * *$ & $.538 * *$ \\
\hline & $(.002)$ & $(.001)$ & $(.072)$ & $(.012)$ \\
\hline Education 9-11 years (Head of Household) & $.282 * *$ & $.105 * *$ & $-2.478 * *$ & $-.375 * *$ \\
\hline & $(.017)$ & $(.006)$ & $(.502)$ & $(.049)$ \\
\hline Education 12-14 years (Head of Household) & $.417 * *$ & $.177 * *$ & $-5.360 * *$ & $-.599 * *$ \\
\hline & $(.019)$ & $(.008)$ & $(.582)$ & $(.057)$ \\
\hline Education 15-17 years (Head of Household) & $.610 * *$ & $.310 * *$ & $-13.491 * *$ & $-1.034 * *$ \\
\hline & $(.028)$ & $(.011)$ & $(.835)$ & $(.084)$ \\
\hline Education $18+$ years (Head of Household) & $.757 * *$ & $.399 * *$ & $-17.905 * *$ & $-1.297 * *$ \\
\hline & $(.026)$ & $(.010)$ & $(.797)$ & $(.081)$ \\
\hline Poor Health Status (Head of Household) & $-.131 * *$ & $-.053 * *$ & $.808 *$ & $.213 * *$ \\
\hline & $(.011)$ & $(.004)$ & $(.306)$ & $(.038)$ \\
\hline Unemployment Index 1-30\% (low affection) & $-.178 * *$ & $-.047 * *$ & $9.042 * *$ & $.846 * *$ \\
\hline & $(.009)$ & $(.003)$ & $(.272)$ & $(.031)$ \\
\hline Unemployment Index $>30 \%$ (high affection) & $-.952 * *$ & $-.165 * *$ & $27.051 * *$ & $2.489 * *$ \\
\hline & $(.012)$ & $(.004)$ & $(.347)$ & $(.044)$ \\
\hline Rural Area ( $<20.000$ inhabitants) & -.008 & $.011 *$ & $1.468 * *$ & $.066+$ \\
\hline & $(.014)$ & $(.005)$ & $(.434)$ & $(.040)$ \\
\hline Big city (> 500.000 inhabitants) & $-.083 * *$ & $-.018 * *$ & $1.396 * *$ & .021 \\
\hline & $(.016)$ & $(.006)$ & $(.492)$ & $(.045)$ \\
\hline Year of observation: 1995 & $.046 * *$ & $-.015 * *$ & $-1.731 * *$ & $-.337 * *$ \\
\hline & $(.006)$ & $(.002)$ & $(.174)$ & $(.024)$ \\
\hline Year of observation: 1996 & .006 & $-.011 * *$ & $-.341 *$ & $-.140 * *$ \\
\hline & $(.006)$ & $(.002)$ & $(.173)$ & $(.023)$ \\
\hline (Constant) & $2.252 * *$ & $3.917 * *$ & $51.001 * *$ & $6.686 * *$ \\
\hline & $(.053)$ & $(.021)$ & $(1.552)$ & $(.213)$ \\
\hline $\mathrm{N}$ of Obs/Groups & & 520 & / 19060 & \\
\hline Mean of Dependent Variable (unweighted) & 4.102 & 4.468 & -3.549 & .391 \\
\hline Overall $\mathrm{R}^{2} \mid$ McKelvey-Zavoina $\mathrm{R}^{2}$ & .50 & .32 & .47 & .86 \\
\hline Wald $\mathrm{Chi}^{2}$ & $26151.69 * *$ & $11917.02 * *$ & $21899.78 * *$ & $5373.13 * *$ \\
\hline
\end{tabular}

1) Average of 1994-1996 income years.

**: $\mathrm{p}<0.01 \quad *: \mathrm{p}<0.05$ +: $\mathrm{p}<0.10$. Col. I-III: Random-Effects GLS Regression; Col. IV: Random Effects Probit.

Ref. Cat.: Native born German living in West Germany; Couple without children; Head of household: less than 9 years of education; household not affected by unemployment; city size of 20.000-500.000 inhabitants; Year of Obs.=1997. Source: SOEP; PSID-GSOEP Equivalent Data File; authors' calculation. 
Table 3b: $\quad$ Effects on Relative Income Positions and Redistribution Effects in Germany, 1995-1997 ${ }^{1}$ : Results from Random-Effects GLS Regression and Probit Models, -Population Living in Households with a Head of Prime Age-

\begin{tabular}{|c|c|c|c|c|}
\hline \multirow{4}{*}{ Variable } & \multicolumn{2}{|c|}{ ln (Relative Income Position) } & \multirow{4}{*}{$\begin{array}{l}\text { Absolute change } \\
\text { in Income } \\
\text { Position due to } \\
\text { Redistribution }\end{array}$} & \multirow{4}{*}{$\begin{array}{c}\text { Positive change } \\
\text { due to } \\
\text { Redistribution } \\
\text { (1=yes) }\end{array}$} \\
\hline & $\begin{array}{l}\text { Pre-Gov’t } \\
\text { Income }\end{array}$ & $\begin{array}{l}\text { Post-Gov't } \\
\text { Income }\end{array}$ & & \\
\hline & & & & \\
\hline & & & & \\
\hline \multirow[t]{2}{*}{ „Pure,, Aussiedler } & $-.434 * *$ & $-.308 * *$ & $9.647 * *$ & $.713^{* *}$ \\
\hline & $(.029)$ & $(.013)$ & $(.954)$ & $(.087)$ \\
\hline \multirow[t]{2}{*}{ „Mixed,, Aussiedler } & .006 & -.006 & 1.927 & -.197 \\
\hline & $(.040)$ & $(.019)$ & $(1.294)$ & $(.128)$ \\
\hline \multirow[t]{2}{*}{ „Pure,, Foreigner } & $-.225 * *$ & $-.222 * *$ & .591 & $-.308 * *$ \\
\hline & $(.017)$ & $(.008)$ & $(.574)$ & $(.053)$ \\
\hline \multirow[t]{2}{*}{ „Mixed,, Foreigner } & -.016 & $-.027 *$ & $-2.098 *$ & $-.260 * *$ \\
\hline & $(.028)$ & $(.013)$ & $(.894)$ & $(.088)$ \\
\hline \multirow[t]{2}{*}{ East Germany } & $-.249 * *$ & $-.142 * *$ & $9.412 * *$ & $.634 * *$ \\
\hline & $(.014)$ & $(.006)$ & $(.472)$ & $(.044)$ \\
\hline \multirow[t]{2}{*}{ Single } & $-.430 * *$ & $-.259^{* *}$ & $3.731 * *$ & .062 \\
\hline & $(.022)$ & $(.010)$ & $(.689)$ & $(.078)$ \\
\hline \multirow[t]{2}{*}{ Couple, 1 child } & $-.161 * *$ & $-.092 * *$ & $12.156^{* *}$ & $.462 * *$ \\
\hline & $(.015)$ & $(.006)$ & $(.462)$ & $(.053)$ \\
\hline \multirow[t]{2}{*}{ Couple, 2 children } & $-.37 * *$ & $-.212 * *$ & $17.978 * *$ & $.912 * *$ \\
\hline & $(.016)$ & $(.007)$ & $(.516)$ & $(.057)$ \\
\hline \multirow[t]{2}{*}{ Couple, 3 and more children } & $-.641 * *$ & $-.290 * *$ & $26.561 * *$ & $2.141 * *$ \\
\hline & $(.021)$ & $(.009)$ & $(.653)$ & $(.070)$ \\
\hline \multirow[t]{2}{*}{ Single-Parent } & $-.758 * *$ & $-.356^{* *}$ & $15.975 * *$ & $1.479 * *$ \\
\hline & $(.020)$ & $(.009)$ & $(.629)$ & $(.070)$ \\
\hline \multirow{2}{*}{ Other Type of Household } & $.039 *$ & $.043 * *$ & $7.816 * *$ & $.551 * *$ \\
\hline & $(.015)$ & $(.007)$ & $(.487)$ & $(.053)$ \\
\hline \multirow[t]{2}{*}{ Age (Head of Household) } & $.116^{* *}$ & $.042 * *$ & $-3.818 * *$ & $-.314 * *$ \\
\hline & $(.004)$ & $(.001)$ & $(.129)$ & $(.013)$ \\
\hline \multirow[t]{2}{*}{$($ Age $* * 2) / 100$ (Head of Household) } & $-.14 * *$ & $-.043 * *$ & $4.637 * *$ & $.375 * *$ \\
\hline & $(.005)$ & $(.002)$ & $(.160)$ & $(.017)$ \\
\hline \multirow[t]{2}{*}{ Education 9-11 years (Head of Household) } & $.236 * *$ & $.085^{* *}$ & $-5.045^{* *}$ & $-.387 * *$ \\
\hline & $(.016)$ & $(.007)$ & $(.520)$ & $(.052)$ \\
\hline Education 12-14 years (Head of Household) & $.344 * *$ & $.156^{* *}$ & $-7.827 * *$ & $-.601 * *$ \\
\hline & $(.019)$ & $(.008)$ & $(.592)$ & $(.060)$ \\
\hline Education 15-17 years (Head of Household) & $.520 * *$ & $.277 * *$ & $-17.964 * *$ & $-1.117 * *$ \\
\hline & $(.026)$ & $(.012)$ & $(.824)$ & $(.088)$ \\
\hline Education $18+$ years (Head of Household) & $.683 * *$ & $.380 * *$ & $-21.784 * *$ & $-1.332 * *$ \\
\hline & $(.025)$ & $(.011)$ & $(.793)$ & $(.085)$ \\
\hline Poor Health Status (Head of Household) & $-.160 * *$ & $-.055 * *$ & $2.240 * *$ & $.239 * *$ \\
\hline & $(.011)$ & $(.004)$ & $(.327)$ & $(.040)$ \\
\hline Unemployment Index 1-30\% (low affection) & $-.183 * *$ & $-.050 * *$ & $8.840 * *$ & $.869 * *$ \\
\hline & $(.008)$ & $(.003)$ & $(.264)$ & $(.032)$ \\
\hline Unemployment Index > 30\% (high affection) & $-.899 * *$ & $-.176 * *$ & $25.525 * *$ & $2.500 * *$ \\
\hline & $(.011)$ & $(.005)$ & $(.351)$ & $(.046)$ \\
\hline Rural Area (<20.000 inhabitants) & -.013 & $.015^{*}$ & $1.565 * *$ & $.070+$ \\
\hline & $(.013)$ & $(.006)$ & $(.421)$ & $(.042)$ \\
\hline Big city (> 500.000 inhabitants) & $-.066 * *$ & $-.024 * *$ & $1.047 *$ & .019 \\
\hline & $(.015)$ & $(.007)$ & $(.477)$ & $(.047)$ \\
\hline Year of observation: 1995 & $.036 * *$ & $-.013 * *$ & $-1.626 * *$ & $-.320 * *$ \\
\hline & $(.006)$ & $(.002)$ & $(.179)$ & $(.024)$ \\
\hline Year of observation: 1996 & .009 & $-.010 * *$ & -.255 & $-.136 * *$ \\
\hline & $(.006)$ & $(.002)$ & $(.177)$ & $(.024)$ \\
\hline (Constant) & $2.381 * *$ & $3.640 * *$ & $47.537 * *$ & $\begin{array}{c}4.354 * * \\
(259)\end{array}$ \\
\hline $\mathrm{N}$ of Obs/Groups & & 454 & 17044 & \\
\hline Mean of Dependent Variable (unweighted) & 4.390 & 4.475 & -12.781 & .316 \\
\hline Overall $R^{2} \mid$ McKelvey-Zavoina $R^{2}$ & .36 & .34 & .30 & .63 \\
\hline Wald $\mathrm{Chi}^{2}$ & $13157.92 * *$ & $11143.13^{* *}$ & $11200.38 * *$ & $4399.03 * *$ \\
\hline
\end{tabular}

Ref. Cat.: Native born German living in West Germany; Couple without children; Head of household: less than 9 years of education; household not affected by unemployment; city size 20.000-500.000 inhabitants; Year of Obs.=1997. Source: SOEP; PSID-GSOEP Equivalent Data File; authors' calculation. 
Table 3c: $\quad$ Effects on Relative Income Positions and Redistribution Effects in Germany, 1995-1997 ${ }^{1}$ : Results from Random-Effects GLS Regression and Probit Models, -Immigrant Population Living in Households with a Head of Prime Age-

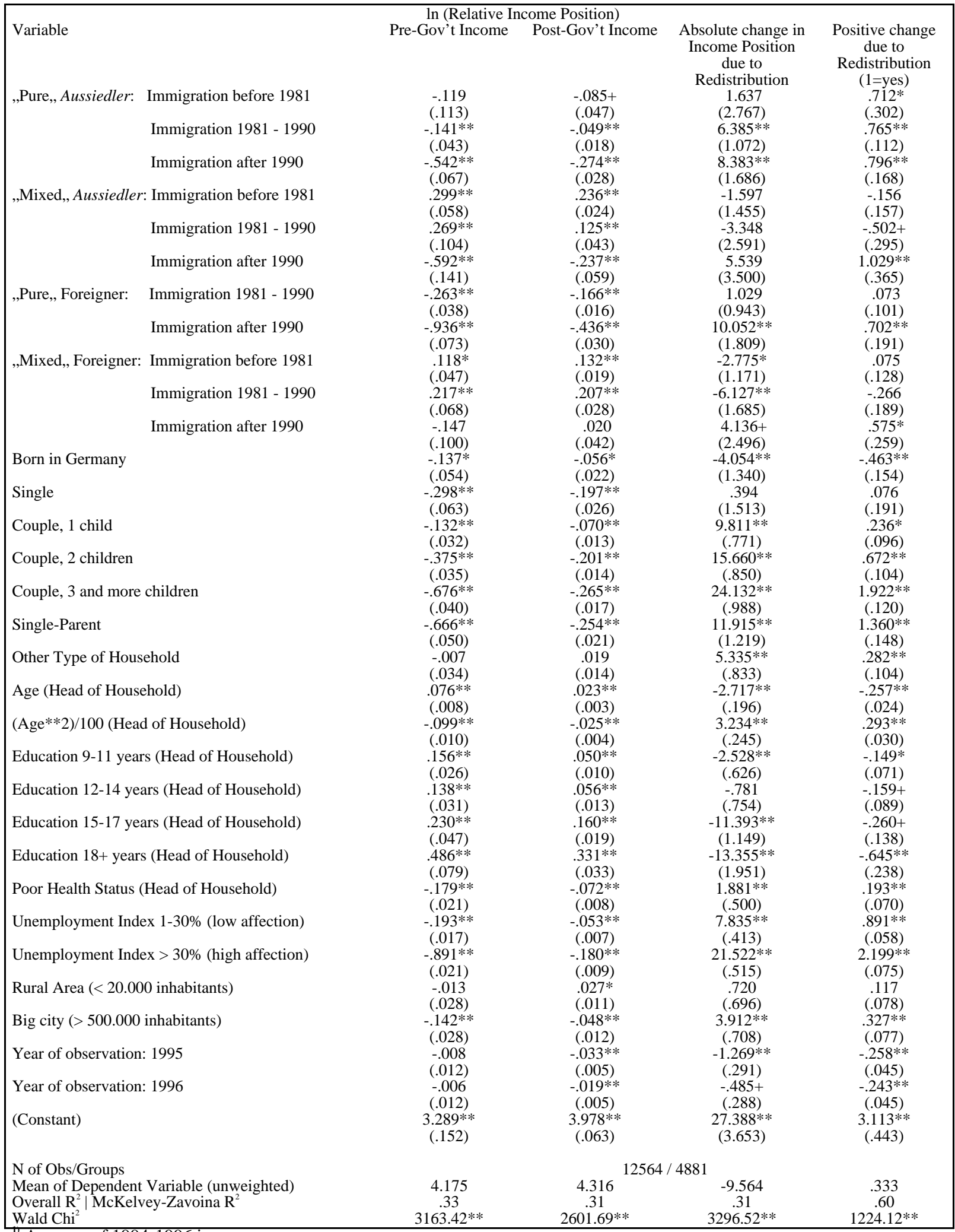

Average of 1994-1996 income years

**: $\mathrm{p}<0.01$ *: $\mathrm{p}<0.05$ +: $\mathrm{p}<0.10$. Col. I-III: Random-Effects GLS Regression; Col. IV: Random Effects Probit.

Ref. Cat.: ,Pure,, Foreigner, immigrated before 1981; Couple without children; Head of household: less than 9 years of education; household not affected by unemployment; city size 20.000-500.000 inhabitants; Year of Obs.=1997.

Source: SOEP; PSID-GSOEP Equivalent Data File; authors' calculation. 


\section{$\underline{\text { Appendix: }}$}

Table A1: $\quad$ Population in Germany, 1995-1997, by Ethnic Group (in \%)

\begin{tabular}{|c|c|c|}
\hline & $\begin{array}{l}\text { Total Population of } \\
\text { Persons in Private } \\
\text { Households }\end{array}$ & $\begin{array}{c}\text { Persons in Private } \\
\text { Households with Heads of } \\
\text { Prime Age }\end{array}$ \\
\hline \multicolumn{3}{|l|}{. West Germany } \\
\hline - Native Born German & 64.8 & 63.3 \\
\hline - Immigrants and Foreigners & 16.1 & 17.6 \\
\hline Aussiedler, total & 5.6 & 5.6 \\
\hline „Pure, , Aussiedler & 3.4 & 3.3 \\
\hline „Mixed,, Aussiedler & 2.2 & 2.3 \\
\hline Foreigners, total & 10.5 & 12.0 \\
\hline „Pure,, Foreigners & 7.5 & 8.6 \\
\hline „Mixed,, Foreigners & 3.0 & 3.4 \\
\hline - East Germany & 19.1 & 19.1 \\
\hline Total Population & 100.0 & 100.0 \\
\hline
\end{tabular}

Source: SOEP; PSID-GSOEP Equivalent Data File; authors’ calculation.

Table A2: $\quad$ Population in Germany, 1995-1997, by Ethnic Group and Immigration Period (in \%)

\begin{tabular}{|c|c|c|c|c|c|c|c|}
\hline & \multirow{2}{*}{$\begin{array}{l}\text { Native } \\
\text { Born }\end{array}$} & \multicolumn{5}{|c|}{ Immigration Period } & \multirow[t]{2}{*}{ Total } \\
\hline & & $1949-60$ & $1961-70$ & 1971-80 & $1981-90$ & $>1990$ & \\
\hline \multicolumn{8}{|l|}{. West Germany } \\
\hline Native Born German & 100 & - & - & - & - & - & 100 \\
\hline „Pure,, Aussiedler & - & 13 & 5 & 9 & 56 & 17 & 100 \\
\hline „Mixed,, Aussiedler & - & 31 & 34 & 17 & 12 & 6 & 100 \\
\hline „Pure,, Foreigners & 5 & 1 & 19 & 43 & 24 & 8 & 100 \\
\hline „Mixed,, Foreigners & 24 & 5 & 19 & 20 & 20 & 12 & 100 \\
\hline East Germany & 100 & - & - & - & - & - & 100 \\
\hline Total Population & 84 & 1 & 3 & 5 & 5 & 2 & 100 \\
\hline
\end{tabular}

Source: SOEP; PSID-GSOEP Equivalent Data File; authors' calculation. 
Table A3a: $\quad$ Pre-Government Income Distribution and Inequality in Germany, 1995-1997'), by Ethnic Group

$\underline{\text { Total Population of Persons in Private Households }}$

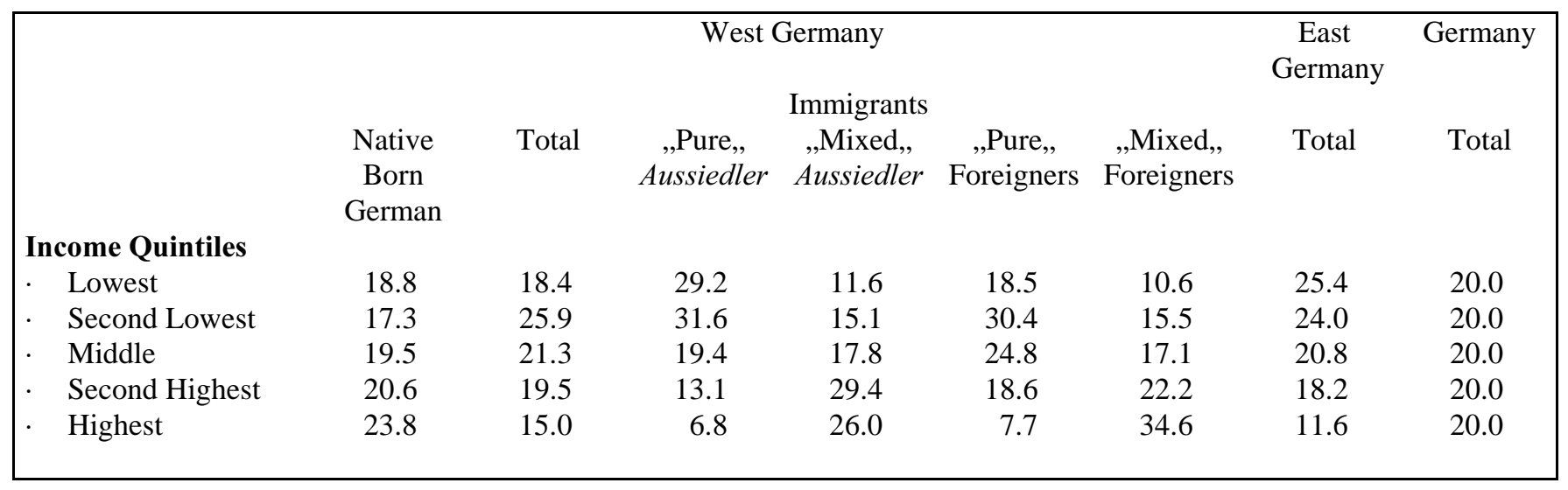

Persons in Private Households with Head of Prime Age

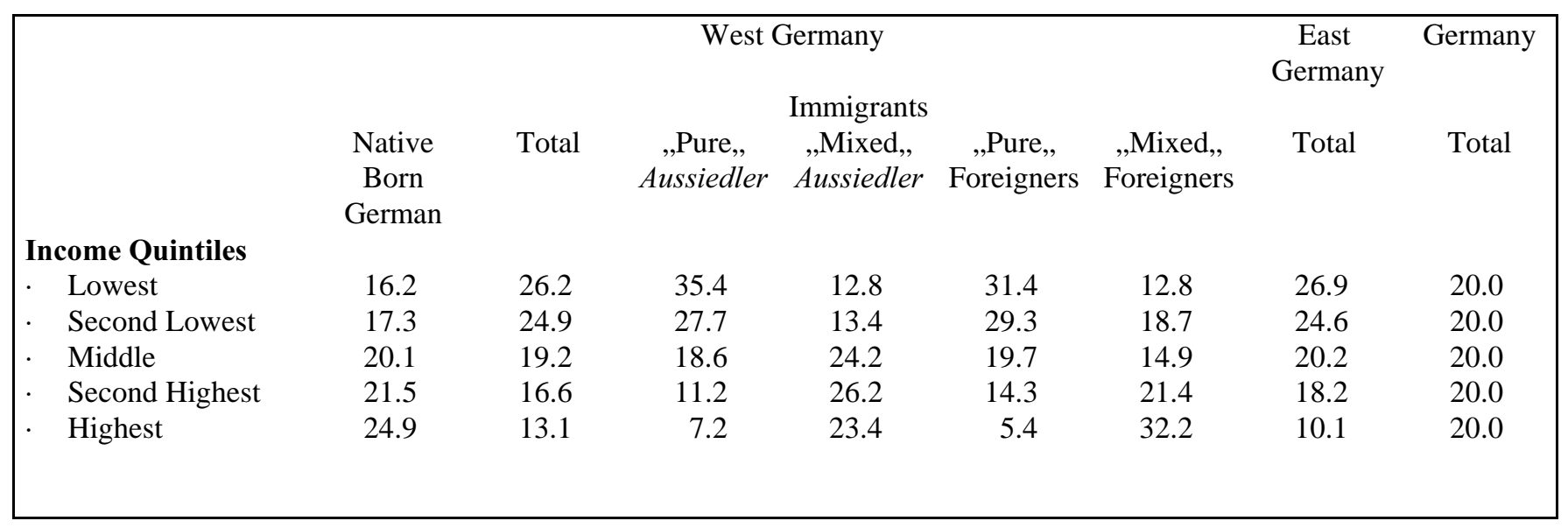

1) All measures give the average of 1994-1996 income years.

Source: SOEP; PSID-GSOEP Equivalent Data File; authors’ calculation. 
Table A3b: Post-Government Income Distribution, Inequality and Poverty in Germany, 1995-1997', by Ethnic Group

Total Population of Persons in Private Households

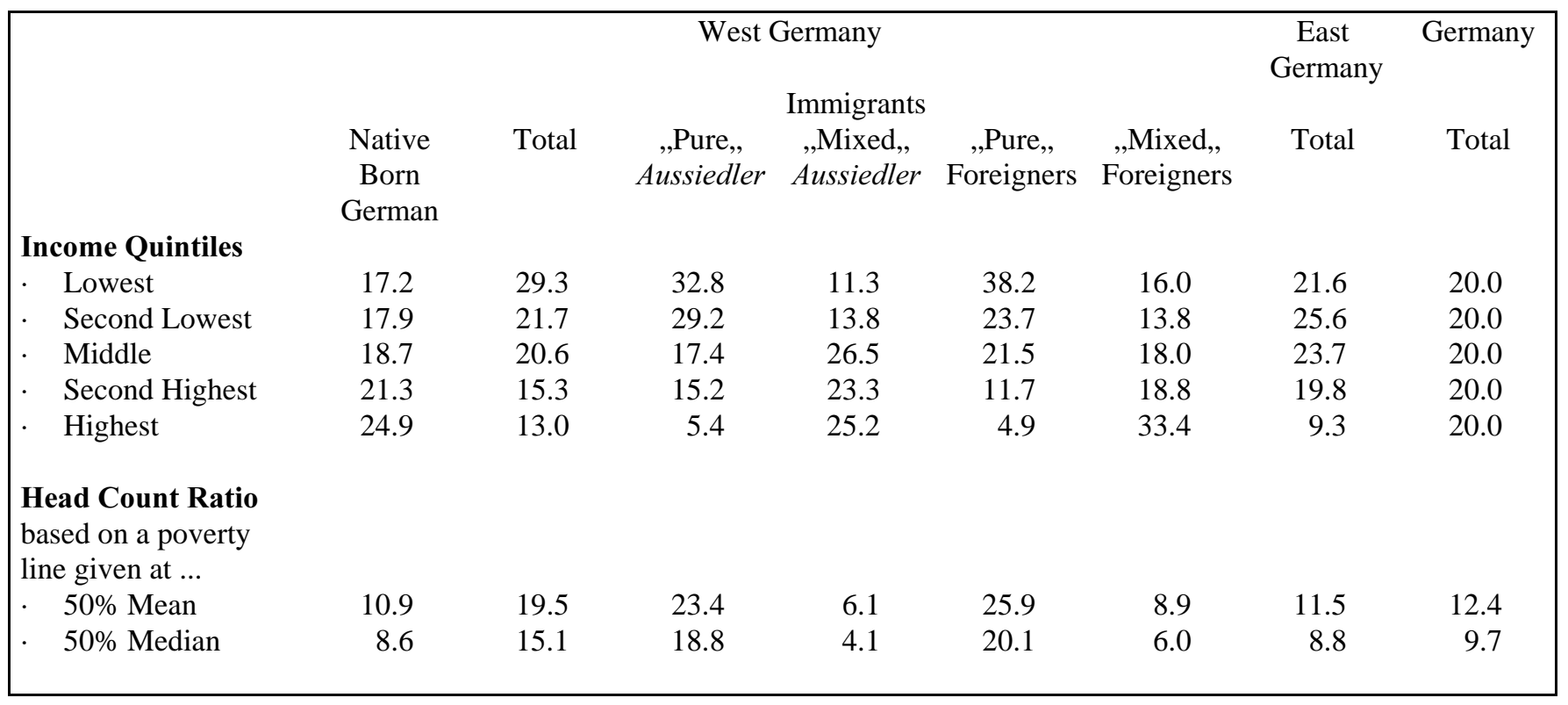

Persons in Private Households with Head of Prime Age

\begin{tabular}{|c|c|c|c|c|c|c|c|c|}
\hline & \multicolumn{6}{|c|}{ West Germany } & \multirow{2}{*}{$\begin{array}{c}\text { East } \\
\text { Germany } \\
\text { Total }\end{array}$} & Germany \\
\hline & $\begin{array}{l}\text { Native } \\
\text { Born } \\
\text { German }\end{array}$ & Total & $\begin{array}{l}\text { „Pure, } \\
\text { Aussiedler }\end{array}$ & $\begin{array}{l}\text { Immigrants } \\
\text { „Mixed,, } \\
\text { Aussiedler }\end{array}$ & $\begin{array}{l}\text { „Pure, } \\
\text { Foreigners }\end{array}$ & $\begin{array}{l}\text { „Mixed," } \\
\text { Foreigners }\end{array}$ & & Total \\
\hline \multicolumn{9}{|l|}{ Income Quintiles } \\
\hline Lowest & 16.8 & 29.4 & 32.7 & 8.3 & 38.9 & 15.8 & 21.9 & 20.0 \\
\hline Second Lowest & 17.7 & 22.6 & 32.0 & 14.3 & 24.6 & 13.4 & 25.3 & 20.0 \\
\hline Middle & 18.9 & 21.6 & 20.1 & 32.0 & 20.5 & 18.8 & 22.3 & 20.0 \\
\hline - Second Highest & 21.5 & 13.6 & 10.6 & 19.5 & 11.0 & 19.4 & 20.8 & 20.0 \\
\hline - Highest & 25.1 & 12.8 & 4.6 & 25.8 & 5.0 & 32.6 & 9.7 & 20.0 \\
\hline \multicolumn{9}{|l|}{$\begin{array}{l}\text { Head Count Ratio } \\
\text { based on a poverty }\end{array}$} \\
\hline $\begin{array}{l}\text { line given at ... } \\
\cdot \quad 50 \% \text { Mean of the } \\
\text { entire population }\end{array}$ & 10.6 & 17.7 & 21.4 & 3.8 & 23.8 & 8.1 & 11.5 & 12.0 \\
\hline $\begin{array}{l}50 \% \text { Median of the } \\
\text { entire population }\end{array}$ & 8.6 & 13.3 & 16.4 & 1.6 & 18.4 & 5.3 & 9.1 & 9.5 \\
\hline
\end{tabular}

1) All measures give the average of 1994-1996 income years.

Source: SOEP; PSID-GSOEP Equivalent Data File; authors' calculation. 
Table A4a: $\quad$ Equivalent Pre- and Post-Government Income in Germany, 1995-19971), by Ethnic Group

$\underline{\text { Total Population of Persons in Private Households }}$

\begin{tabular}{|c|c|c|c|c|}
\hline & $\begin{array}{c}\text { Pre-Government } \\
\text { (=Market) } \\
\text { Income }\end{array}$ & $\begin{array}{c}\text { Non-Market } \\
\text { Income } \\
\text { (Pensions and } \\
\text { Public Transfers) } \\
\text { in } 199\end{array}$ & $\begin{array}{l}\text { Taxes and } \\
\text { Social Security } \\
\text { Contributions } \\
\text { M }\end{array}$ & $\begin{array}{l}\text { Post-Government } \\
\text { Income }\end{array}$ \\
\hline West Germany & & & & \\
\hline - Native Born German & 41,924 & 7,917 & 12,302 & 37,539 \\
\hline - Immigrants and Foreigners & 34,754 & 5,739 & 10,391 & 30,101 \\
\hline · „Pure,, Aussiedler & 25,322 & 8,937 & 7,539 & 26,720 \\
\hline . „Mixed, Aussiedler & 45,673 & 6,539 & 13,835 & 38,377 \\
\hline · „Pure,, Foreigners & 30,315 & 4,453 & 9,184 & 25,584 \\
\hline . „Mixed, Foreigners & 48,923 & 4,676 & 14,237 & 39,362 \\
\hline . East Germany & 30,498 & 9,074 & 8,760 & 30,811 \\
\hline Total Population & 38,581 & 7,786 & 11,316 & 35,050 \\
\hline
\end{tabular}

Persons in Households with heads of prime age

\begin{tabular}{|c|c|c|c|c|}
\hline & $\begin{array}{c}\text { Pre-Government } \\
\text { (=Market) } \\
\text { Income }\end{array}$ & $\begin{array}{c}\text { Non-Market } \\
\text { Income } \\
\text { (Pensions and } \\
\text { Public Transfers) } \\
\text { in } 199\end{array}$ & $\begin{array}{c}\text { Taxes and } \\
\text { Social Security } \\
\text { Contributions }\end{array}$ & $\begin{array}{l}\text { Post-Government } \\
\text { Income }\end{array}$ \\
\hline West Germany & & & & \\
\hline - Native Born German & 49,693 & 3,632 & 14,950 & 38,320 \\
\hline - Immigrants and Foreigners & 37,909 & 4,058 & 11,430 & 30,537 \\
\hline · „Pure,, Aussiedler & 31,421 & 4,747 & 9,601 & 26,567 \\
\hline · „Mixed,, Aussiedler & 50,572 & 4,459 & 15,466 & 39,566 \\
\hline · „Pure, Foreigners & 31,643 & 4,016 & 9,629 & 26,030 \\
\hline · „Mixed, Foreigners & 51,925 & 3,202 & 15,148 & 39,978 \\
\hline . $\quad$ East Germany & 36,493 & 5,740 & 10,631 & 31,602 \\
\hline Total Population & 45,051 & 4,110 & 13,502 & 35,659 \\
\hline
\end{tabular}

1) Average of 1994-1996 income years.

Source: SOEP; PSID-GSOEP Equivalent Data File; authors' calculation. 
Table A4b: $\quad$ Pre- and Post-Government Income Percentiles in Germany, 1995-1997), by Ethnic Group

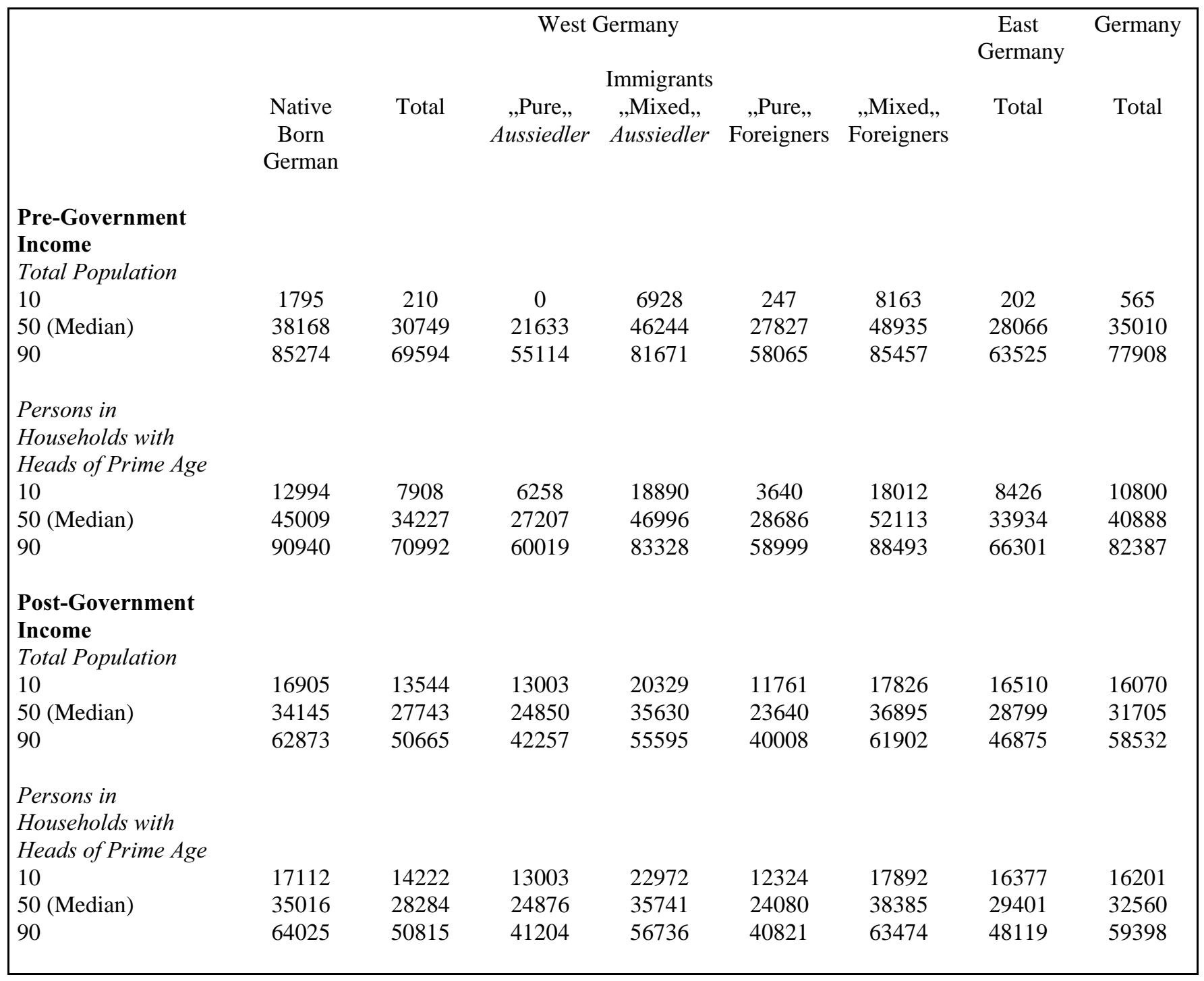

1) Average of 1994-1996 income years.

Source: SOEP; PSID-GSOEP Equivalent Data File; authors' calculation. 
Table A5: $\quad$ Descriptive Statistics for Random Effects Models in Tables 3a,b,c

\begin{tabular}{|c|c|c|c|}
\hline & $\begin{array}{l}\text { Total Population } \\
\text { (see Table 3a) }\end{array}$ & $\begin{array}{l}\text { Prime Age Population } \\
\quad \text { (see Table } 3 b)\end{array}$ & $\begin{array}{c}\text { Immigrant Prime Age Population } \\
\text { (see Table 3c) }\end{array}$ \\
\hline Variable & & Unweighted Mean (Standard Deviation) & \\
\hline $\begin{array}{l}\text { Relative Pre-Government Income } \\
\text { Position (log) }\end{array}$ & $4.102(1.416)$ & $4.390(1.067)$ & $4.175(1.144)$ \\
\hline $\begin{array}{l}\text { Relative Post-Government } \\
\text { Income Position }(\log )\end{array}$ & $4.468(.491)$ & $4.475(.490)$ & $4.316(.464)$ \\
\hline $\begin{array}{l}\text { Absolute change in Income } \\
\text { Position due to Redistribution }\end{array}$ & $-3.549(41.828)$ & $-12.781(32.891)$ & $-9.564(27.732)$ \\
\hline $\begin{array}{l}\text { Positive change due to } \\
\text { Redistribution ( } 1=\text { yes) }\end{array}$ & $.391(.488)$ & $.316(.465)$ & $.333(.471)$ \\
\hline „Pure,, Aussiedler & $.045(.209)$ & $.045(.209)$ & - \\
\hline „Mixed,, Aussiedler & $.018(.134)$ & $.019(.136)$ & - \\
\hline „Mixed,, Foreigner & $.040(.196)$ & $.044(.205)$ & - \\
\hline Immigration 1971 - 1980 & $.082(.275)$ & $.091(.288)$ & - \\
\hline Immigration 1981 - 1990 & $.069(.254)$ & $.076(.265)$ & - \\
\hline Immigration after 1990 & $.022(.147)$ & $.024(.153)$ & - \\
\hline \multicolumn{4}{|l|}{ „Pure,, Aussiedler: } \\
\hline Immigration before 1981 & - & - & $.009(.096)$ \\
\hline Immigration 1981 - 1990 & - & - & $.113(.316)$ \\
\hline Immigration after 1990 & - & - & $.037(.188)$ \\
\hline \multicolumn{4}{|l|}{ „Mixed,, Aussiedler: } \\
\hline Immigration before 1981 & - & - & $.049(.216)$ \\
\hline Immigration 1981 - 1990 & - & - & $.012(.111)$ \\
\hline Immigration after 1990 & - & - & $.007(.083)$ \\
\hline \multicolumn{4}{|l|}{ „Mixed,, Foreigner: } \\
\hline Immigration before 1981 & - & - & $.079(.269)$ \\
\hline Immigration 1981 - 1990 & - & - & $.035(.184)$ \\
\hline Immigration after 1990 & - & - & $.015(.122)$ \\
\hline \multicolumn{4}{|l|}{ „Pure,, Foreigner: } \\
\hline Immigration 1981 - 1990 & - & - & $.115(.319)$ \\
\hline Immigration after 1990 & - & - & $.027(.164)$ \\
\hline Born in Germany & $.753(.430)$ & $.737(.439)$ & $.050(.219)$ \\
\hline Single & $.083(.276)$ & $.053(.225)$ & $.027(.164)$ \\
\hline Couple, 1 child & $.214(.410)$ & $.242(.428)$ & $.245(.430)$ \\
\hline Couple, 2 children & $.203(.402)$ & $.231(.421)$ & $.254(.435)$ \\
\hline Couple, 3 and more children & $.094(.292)$ & $.107(.309)$ & $.150(.357)$ \\
\hline Single-Parent & $.053(.225)$ & $.058(.234)$ & $.043(.203)$ \\
\hline Other Type of Household & $.160(.367)$ & $.169(.375)$ & $.167(.373)$ \\
\hline Age (Head of Household) & 43.553 (13.988) & $39.919(10.042)$ & $39.114(10.517)$ \\
\hline $\begin{array}{l}\left(\text { Age }^{* * 2}\right) / 100(\text { Head of } \\
\text { Household })\end{array}$ & $20.926(13.853)$ & $16.944(8.311)$ & $16.405(8.563)$ \\
\hline $\begin{array}{l}\text { Education 9-11 years (Head of } \\
\text { Household) }\end{array}$ & $.537(.498)$ & $.534(.498)$ & $.416(.492)$ \\
\hline $\begin{array}{l}\text { Education 12-14 years (Head of } \\
\text { Household) }\end{array}$ & $.195(.396)$ & $.205(.404)$ & $.241(.427)$ \\
\hline $\begin{array}{l}\text { Education } 15-17 \text { years (Head of } \\
\text { Household) }\end{array}$ & $.057(.232)$ & $.060(.237)$ & $.073(.260)$ \\
\hline $\begin{array}{l}\text { Education } 18+\text { years (Head of } \\
\text { Household) }\end{array}$ & $.082(.274)$ & $.085(.280)$ & $.025(.156)$ \\
\hline $\begin{array}{l}\text { Poor Health Status (Head of } \\
\text { Household) }\end{array}$ & $.133(.340)$ & $.108(.311)$ & $.124(.330)$ \\
\hline $\begin{array}{l}\text { Unemployment Index 1-30\% } \\
\text { (low affection) }\end{array}$ & $.181(.385)$ & $.199(.399)$ & $.221(.415)$ \\
\hline $\begin{array}{l}\text { Unemployment Index }>30 \% \\
\text { (high affection) }\end{array}$ & $.205(.404)$ & $.132(.338)$ & $.173(.378)$ \\
\hline Rural Area ( $<20.000$ inhabitants $)$ & $.440(.496)$ & $.445(.497)$ & $.326(.469)$ \\
\hline Big city (> 500.000 inhabitants) & $.298(.457)$ & $.293(.455)$ & $.372(.483)$ \\
\hline Year of observation: 1995 & $.340(.473)$ & $.342(.474)$ & $.350(.477)$ \\
\hline Year of observation: 1996 & $.333(.471)$ & $.333(.471)$ & $.330(.470)$ \\
\hline Number of Observations & 52050 & 45495 & 12564 \\
\hline
\end{tabular}

Source: SOEP; PSID-GSOEP Equivalent Data File; authors' calculation. 
Figure 1:

Migration Patterns between Germany and abroad, 1984-1998*

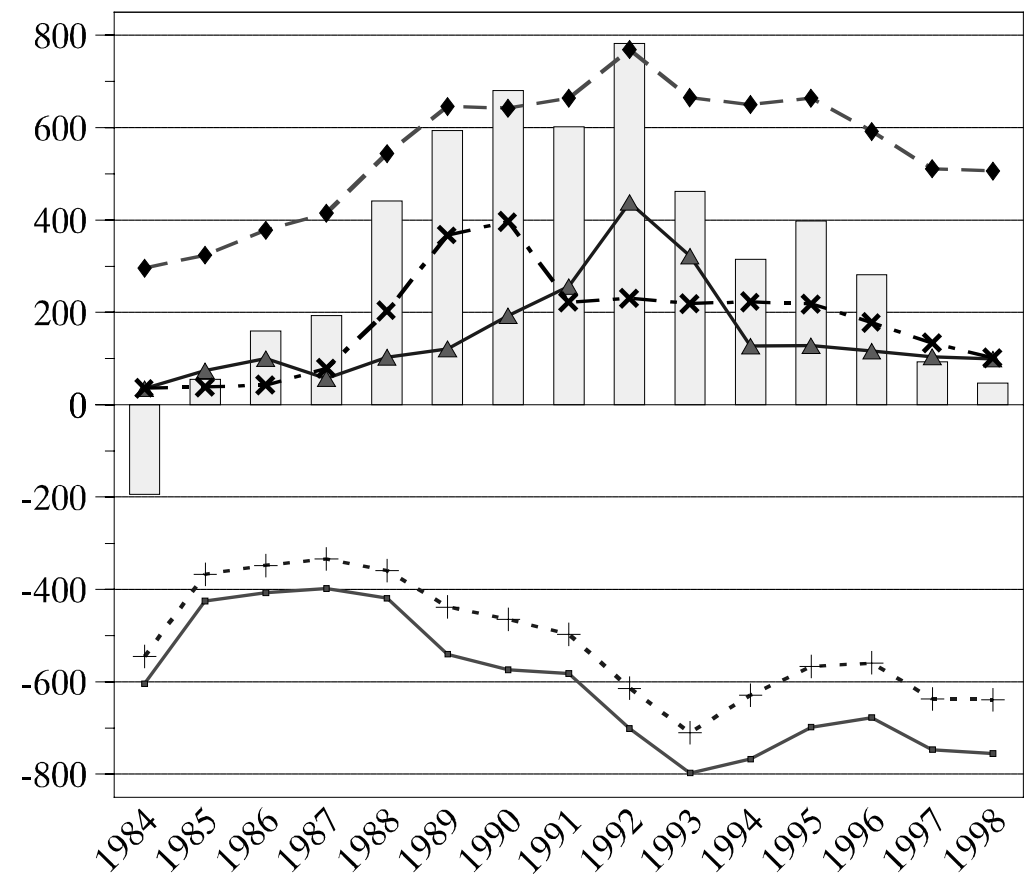

$\triangle$ Asylum/Refugees

- Other For. Immigrants

* Aussiedler

$\square$ Net Migration

$\div$ Foreign Emigration

$\rightarrow$ Total Emigration

* 1984-1990 West Germany.

Source: Statistisches Bundesamt 1999; Enquete-Kommission "Demographischer Wandel" 1998. 
Figure 2a: Re-Distribution Effects in Germany, by Ethnic Groups 1995-1997

- Share of Winners* -

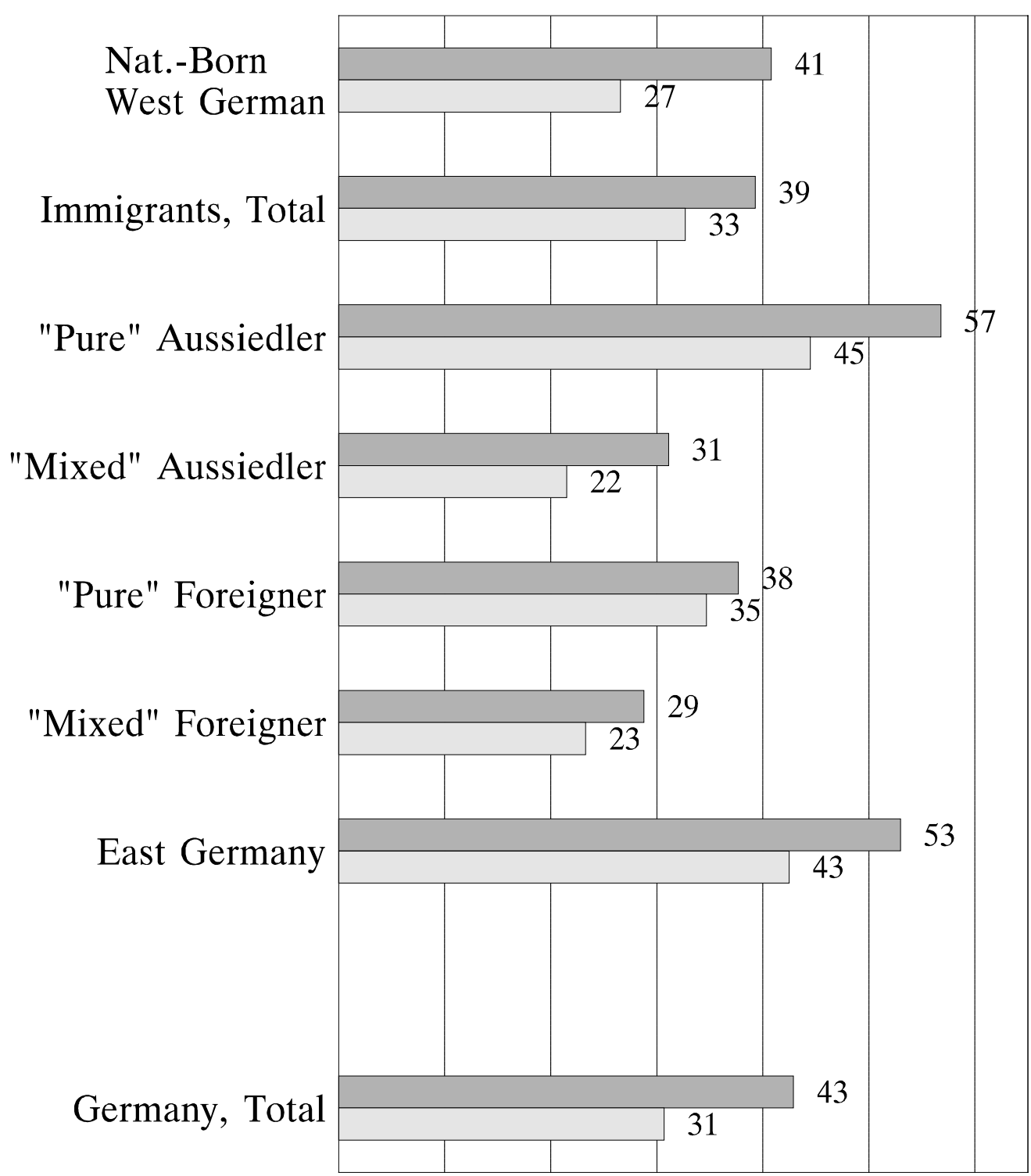

Population Share (\%)

\section{Total Population $\square$ Prime Age Heads}

* Relative Post-Government Income Position > Relative Pre-Government Income Position. Source: SOEP; PSID-GSOEP Equivalent Data File; authors' calculations. 
Figure 2b: Re-Distribution Effects in Germany, by Ethnic Groups 1995-1997

- Difference of Relative Post- and Pre-Government Income Position* -

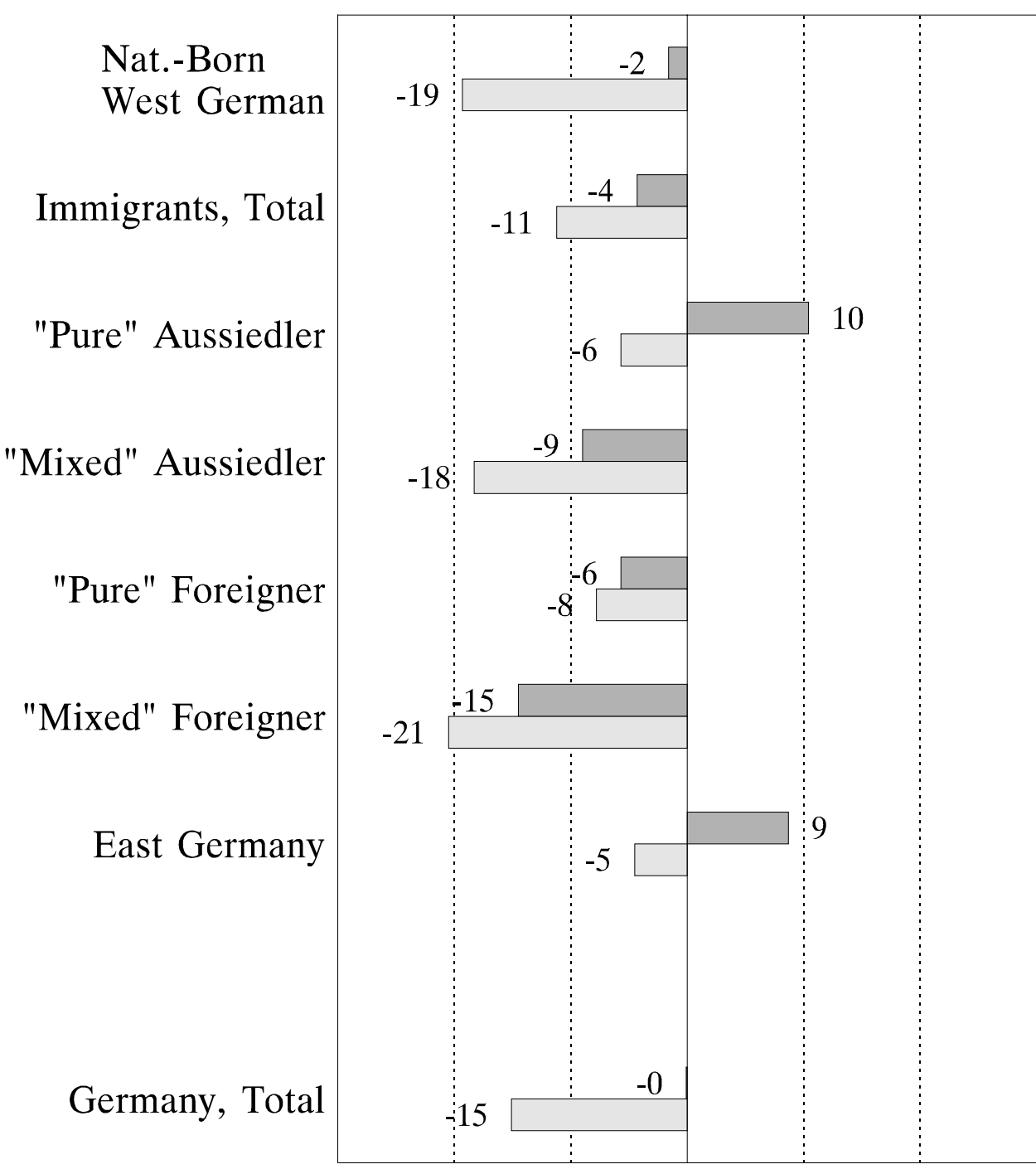

Difference (\%-Points)

\section{$\square$ Total Population $\square$ Prime Age Heads}

* Group-specific Means of Individual Differences.

Source: SOEP; PSID-GSOEP Equivalent Data File; authors' calculations. 
Figure 3: Re-Distribution Effects in Germany, by Ethnic Groups 1995-1997

- Predicted Difference of Relative Post- and Pre-Government Income Position* -

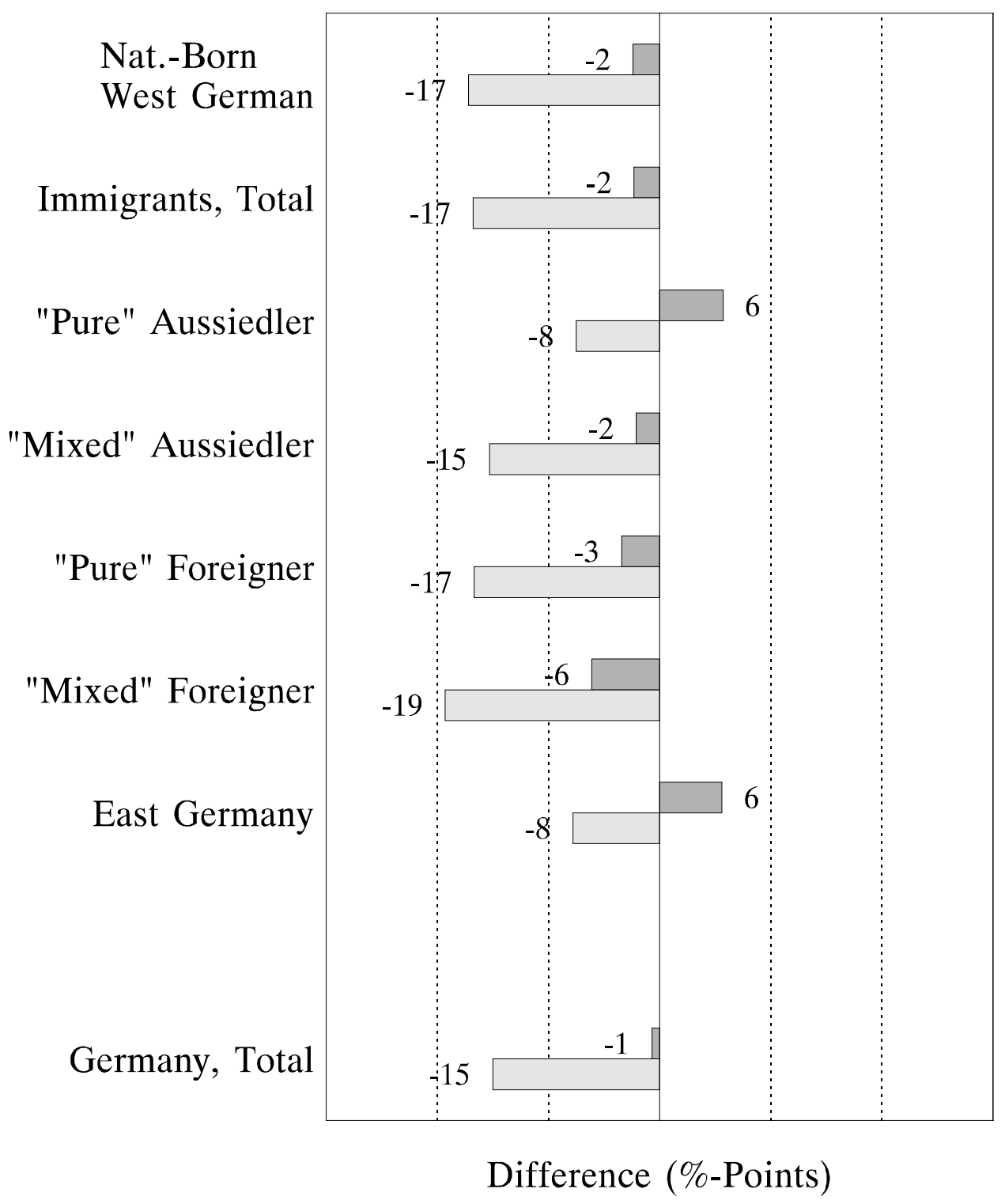

\section{$\square$ Total Population $\square$ Prime Age Heads}

* Based on Results from Random-Effects GLS Models.

Source: SOEP; PSID-GSOEP Equivalent Data File; authors' calculations. 


\section{IZA Discussion Papers}

No. Author(s)

21
J. Ondrich
C. K. Spiess
Q. Yang
G. G. Wagner

22
A. Million
R. Rotte
K. F. Zimmermann

23

T. Bauer

K. F. Zimmermann

24 K. F. Zimmermann

M. C. Burda

J. von Hagen

K. Konrad

F. Schneider

G. G. Wagner

K. Papps

R. Winkelmann

26

D. Enste

F. Schneider

27

E. Bratberg

$\varnothing$. A. Nilsen

28

U. Broll

K. P. Wong

D. J. Snower

30

J. Kluve

H. Lehmann

C. M. Schmidt

31

C. M. Schmidt

32

S.- A. Dahl

$\varnothing$. A. Nilsen

K. Vaage

A. Lindbeck

D. J. Snower

34
Title

Area

Date

The Liberalization of Maternity Leave Policy and

$1 / 3$

9/98

the Return to Work after Childbirth in Germany

The Economics of Hospital Trips and Health Care 3

$9 / 98$

Reform

Learning Efficiency of Economics Students

7

$9 / 98$

Petersberger Erklärung: Anstöße für eine

$1 / 3$

$10 / 98$

zukunftsgerichtete Arbeitsmarktpolitik

Unemployment and Crime: New Answers to an

Old Question

Increasing Shadow Economies All Over the

World - Fiction or Reality?

Transitions from School to Work: Search Time and Job Duration

Efficiency Wages and Futures Markets

$1 / 7$

$1 / 99$

Causes of Changing Earnings Inequality

Active Labor Market Policies in Poland:

$1 / 99$

Human Capital Enhancement, Stigmatization or Benefit Churning?

Persistence and the German Unemployment

Problem: Empirical Evidence on German Labor Market Flows

Work or Retirement? Exit Routes for Norwegian Elderly

Price Dynamics and Production Lags 
Is Job Stability in the United States Falling?

Reconciling Trends in the Current Population

1

Survey and Panel Study of Income Dynamics

The Effects of European Economic and Monetary

Union on Wage Behaviour

37 H. S. Buscher

Exchange Rate Volatility Effects on the German

Job Satisfaction within the Scottish Academic

Multi-Task Learning and the Reorganization of

Work

Empirical Findings on the Swiss Migration

Anatomy of Policy Complementarities

Household Characteristics, Ability and Education: Evidence from a Dynamic Expected Utility Model

The Effects of Development on Migration:

Theoretical Issues and New Empirical Evidence

Tenure-based Wage Setting

Overtime Work and Overtime Compensation in Germany

51 A. Barrett

P. J. O'Connell
J. Mayer
R. T. Riphahn

Ethnic German Migration After 1989 - Balance and Perspectives

Does Training Generally Work?

The Returns to In-Company Training

Fertility Assimilation of Immigrants: Evidence from Count Data Models

Inter-industry Wage Dispersion in Portugal: high 7 but falling 


\begin{tabular}{|c|c|c|c|c|}
\hline 55 & L. Goerke & $\begin{array}{l}\text { Value-added Tax versus Social Security } \\
\text { Contributions }\end{array}$ & 3 & $8 / 99$ \\
\hline 56 & $\begin{array}{l}\text { A. Lindbeck } \\
\text { D. J. Snower }\end{array}$ & $\begin{array}{l}\text { Centralized Bargaining and Reorganized Work: } \\
\text { Are they compatible? }\end{array}$ & $1 / 5$ & 9/99 \\
\hline 57 & $\begin{array}{l}\text { I. N. Gang } \\
\text { K. F. Zimmermann }\end{array}$ & $\begin{array}{l}\text { Is Child like Parent? } \\
\text { Educational Attainment and Ethnic Origin }\end{array}$ & 1 & $9 / 99$ \\
\hline 58 & $\begin{array}{l}\text { T. Bauer } \\
\text { K. F. Zimmermann }\end{array}$ & Occupational Mobility of Ethnic Migrants & 1 & 9/99 \\
\hline 59 & $\begin{array}{l}\text { D. J. DeVoretz } \\
\text { S. A. Laryea }\end{array}$ & $\begin{array}{l}\text { Canadian Immigration Experience: } \\
\text { Any Lessons for Europe? }\end{array}$ & $1 / 2 / 3$ & 9/99 \\
\hline 60 & $\begin{array}{l}\text { C. Belzil } \\
\text { J. Hansen }\end{array}$ & $\begin{array}{l}\text { Subjective Discount Rates, Intergenerational } \\
\text { Transfers and the Return to Schooling }\end{array}$ & 7 & $10 / 99$ \\
\hline 61 & R. Winkelmann & Immigration: The New Zealand Experience & 7 & $10 / 99$ \\
\hline 62 & A. Thalmaier & $\begin{array}{l}\text { Bestimmungsgründe von Fehlzeiten: Welche } \\
\text { Rolle spielt die Arbeitslosigkeit? }\end{array}$ & 3 & $10 / 99$ \\
\hline 63 & M. Ward & Your Everyday, Average Academic & 5 & $10 / 99$ \\
\hline 64 & M. Ward & $\begin{array}{l}\text { Salary and the Gender Salary Gap in the } \\
\text { Academic Profession }\end{array}$ & 5 & $10 / 99$ \\
\hline 65 & $\begin{array}{l}\text { H. Lehmann } \\
\text { J. Wadsworth } \\
\text { A. Acquisti }\end{array}$ & $\begin{array}{l}\text { Grime and Punishment: Job Insecurity and Wage } \\
\text { Arrears in the Russian Federation }\end{array}$ & 4 & $10 / 99$ \\
\hline 66 & $\begin{array}{l}\text { E. J. Bird } \\
\text { H. Kayser } \\
\text { J. R. Frick } \\
\text { G. G. Wagner }\end{array}$ & $\begin{array}{l}\text { The Immigrant Welfare Effect: Take-Up or } \\
\text { Eligibility? }\end{array}$ & 3 & $10 / 99$ \\
\hline 67 & $\begin{array}{l}\text { R. T. Riphahn } \\
\text { A. Thalmaier }\end{array}$ & $\begin{array}{l}\text { Behavioral Effects of Probation Periods: } \\
\text { An Analysis of Worker Absenteeism }\end{array}$ & $1 / 3$ & $10 / 99$ \\
\hline 68 & B. Dietz & $\begin{array}{l}\text { Ethnic German Immigration from Eastern Europe } \\
\text { and the former Soviet Union to Germany: the } \\
\text { Effects of Migrant Networks }\end{array}$ & 1 & $11 / 99$ \\
\hline 69 & M.-S. Yun & $\begin{array}{l}\text { Generalized Selection Bias and the Decomposition } \\
\text { of Wage Differentials }\end{array}$ & 7 & $11 / 99$ \\
\hline 70 & $\begin{array}{l}\text { I. N. Gang } \\
\text { F.L. Rivera-Batiz }\end{array}$ & $\begin{array}{l}\text { Immigrants and Unemployment in the European } \\
\text { Community }\end{array}$ & 1 & $11 / 99$ \\
\hline 71 & L. Goerke & The Wedge & 3 & $11 / 99$ \\
\hline 72 & $\begin{array}{l}\text { J. Fersterer } \\
\text { R. Winter-Ebmer }\end{array}$ & $\begin{array}{l}\text { Are Austrian Returns to Education Falling Over } \\
\text { Time? }\end{array}$ & 7 & $11 / 99$ \\
\hline 73 & $\begin{array}{l}\text { G. S. Epstein } \\
\text { S. Nitzan }\end{array}$ & The Endogenous Determination of Minimum Wage & 3 & $11 / 99$ \\
\hline
\end{tabular}


Knowing What Works: The Case for Rigorous

Entry Decision into Self-Employment from Transition Economies

80 J. C. van Ours

The Netherlands: Old Emigrants - Young 
An Evaluation of Public Employment Programmes in the East German State of Sachsen-Anhalt

97 A. Barrett

L. Husted

H. S. Nielsen

M. Rosholm

N. Smith

102 B. van der Klaauw

J. C. van Ours

K. Brännäs

104

S. Kohns

105
G. Brunello
C. Graziano
B. Parigi

106
L. Bellmann
S. Bender
U. Hornsteiner

107 J. C. van Ours

G. Ridder

108 J. Boone

J. C. van Ours

109 G. J. van den Berg

B. van der Klaauw

D. DeVoretz

C. Werner
Irish Migration: Characteristics, Causes and 1 Consequences

Industry Wage Differentials Revisited: A

Longitudinal Comparison of Germany and USA

Residential Location and Youth Unemployment:

\section{Transitions}

Immigrant Assimilation and Welfare Participation: 1/3/7

Do Immigrants Assimilate Into or Out-of Welfare?

Employment and Wage Assimilation of Male First 3 Generation Immigrants in Denmark

Estimation in a Duration Model for Evaluating

Different Skill Levels and Firing Costs in a

Matching Model with Uncertainty -

An Extension of Mortensen and Pissarides (1994)

Ownership or Performance: What Determines

Board of Directors' Turnover in Italy?

Job Tenure of Two Cohorts of Young German Men
1979 - 1990: An analysis of the (West-)German Employment Statistic Register Sample concerning multivariate failure times and unobserved heterogeneity

Fast Track or Failure: A Study of the Completion Rates of Graduate Students in Economics

Modeling Financial Incentives to Get Unemployed

Back to Work

Combining Micro and Macro Unemployment 
K. Terrell

112 L. Bellmann

T. Schank

113 R. Euwals

114 G. Brunello

A. Medio

115 A. Cigno

F. C. Rosati

116 C. Belzil

117 S. Bender

A. Haas

C. Klose

118 M. A. Shields

M. E. Ward

119 A. Lindbeck

D. J. Snower

120 P. T. Pereira

P. S. Martins

121

J. C. van Ours

122

D. Munich

J. Svejnar

K. Terrell

123 J. Hunt

124 R. T. Riphahn

125 F. Büchel

J. R. Frick
Sectoral Restructuring and Labor Mobility:

A Comparative Look at the Czech Republic

Innovations, Wages and Demand for

5

Heterogeneous Labour: New Evidence from a

Matched Employer-Employee Data-Set

Do Mandatory Pensions Decrease Household

Savings? Evidence for the Netherlands

An Explanation of International Differences in

Education and Workplace Training

Why do Indian Children Work, and is it Bad for

Them?

Unemployment Insurance and Subsequent Job

Duration: Job Matching vs. Unobserved

Heterogeneity

IAB Employment Subsample 1975-1995.

Opportunities for Analysis Provided by the

Anonymised Subsample

Improving Nurse Retention in the British National

Health Service: The Impact of Job Satisfaction on

Intentions to Quit

The Division of Labor and the Market for

Organizations

Does Education Reduce Wage Inequality?

Quantile Regressions Evidence from Fifteen

European Countries

5

$2 / 00$

Do Active Labor Market Policies Help Unemployed $\quad 4 / 6 \quad 3 / 00$

Workers to Find and Keep Regular Jobs?

Returns to Human Capital under the Communist

Wage Grid and During the Transition to a Market

Economy

Why Do People Still Live in East Germany?

$3 / 00$

Rational Poverty or Poor Rationality? The Take-up of Social Assistance Benefits

The Income Portfolio of Immigrants in Germany -

Effects of Ethnic Origin and Assimilation. Or:

Who Gains from Income Re-Distribution?

$1 / 4$ 